\title{
CARTOGRAPHIC IMAGE OF SAMOGITIA IN THE OLD MAPS OF LITHUANIA, POLAND AND OTHER NEIGHBORING COUNTRIES (1700-1939)
}

\author{
Viktoras Lukoševičius \\ University of Šiauliai, Department of Technology, Vilnius g.141, LT-76353 Šiauliai, Lithuania \\ E-mail: viktoras.lukosevicius@ktu.lt
}

Received 15 January 2014; accepted 10 June 2014

\begin{abstract}
While continuing researches on ancient cartography (Lukoševičius 2014) the publication is aimed at viewing maps of Samogitia in the perspective of historical events, with a special emphasis on most important historical events as well as cartography development moments. The method used is analysis the most representitive examples of maps, by different authors, found in cartographical archives. The article presents the authors and designers over 60 maps where Samogitia is marked and discusses map characteristics. It also provides links that are helpful for the readers interested in a more detailed studies of specific maps. Such presentation should help revise and complete the historical image of Samogitia because the old maps were not specific to any one topic. They - the universal, they were reflected in both the natural and social phenomena and the evolution of patterns. It was also available and various historical comments. Often, the old maps are often associated with military needs.

Summarizing research results the author conclude that presented ancient maps is important for the history of Lithuania cartography and are true historical witnesses helping to understand long and complicated formation process of Samogitia and the state of Lithuania; however the analysis alone is insufficient to fully reveal its historic concept.
\end{abstract}

Keywords: Žemaitija, Samogitia, Samogitians, Christianity, historical destiny, old maps, map creators, ethnic land, etnographic area.

Reference to this paper should be made as follows: Lukoševičius, V. 2014, Cartographic image of Samogitia in the old maps of Lithuania, Poland and other neighboring countries (1700-1939), Geodesy and Cartography 40(2): 75-97.

\section{The maps illustrating the history of Samogitia in the 18th century}

In 1702, January 27 Carol XII together with the Swedish military forces crossed the border of the Grand Duchy of Lithuania and marched into Samogitia. By February 17 the Army had reached Raseiniai. Over the years 1710-1711 plague was widely spread in Samogitia and due to that entire villages were left deserted. Samogitia lost almost $1 / 3$ of its population.

In 1764 Samogitia was subdivided into two, and in 1791 - into three powiets (Lithuanian: singular pavietas, plural - pavietai), with its centres accordingly Raseinai, Šiauliai and Telšiai.

After the third division of the Republic, in 1795, Samogitia was passed on to Russia. In the same year the entire left bank of the Nemunas starting with Baltstoge till Šakiai was attached to Prussia, while the other part, unofficially called Užnemunė by Lithuanians and Samogitians in the $19^{\text {th }}$ century, was incorporated into Warsaw Duchy, which had been in existence for five years and depended on Napoleon's France.

The maps, dated the $18^{\text {th }}$ century reflect the decline of the state of Lithuania and at the same time the decline of Samogitia which ended in the division of Lithuania- Poland and incorporation of Lithuania into the Russian Empire.

The maps of Lithuania published in Western Europe in the $17^{\text {th }}$ and the first half of the $18^{\text {th }}$ centuries were the products of remake of the map of Lithuania, dated 1613. On these maps owing to the hydrographical survey carried out by Swedes and Germans only the contours of the Baltic Sea-coast were modified: the shoreline of the Firth Kurshiai Marios gradually 


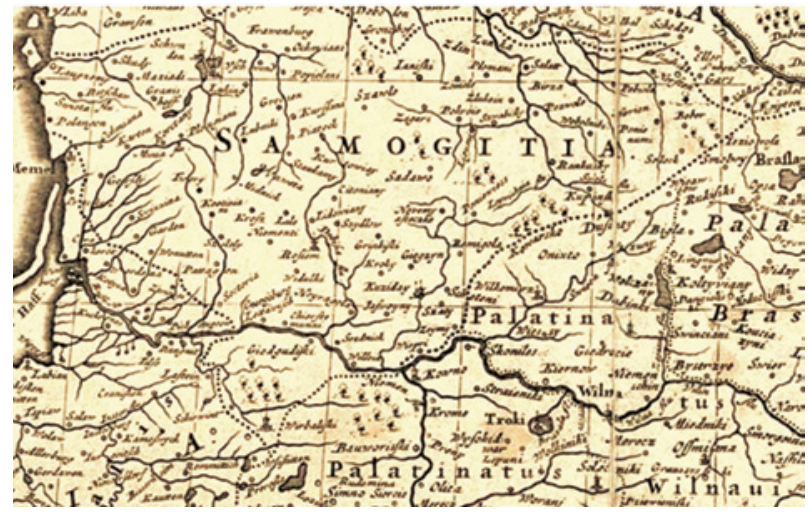

Fig. 1. Samogitia on the map of Poland and Grand Duchy of Lithuania by Frederick de Witt, Amsterdam 1698-1702

Source: http://www.lithuanianmaps.com/images/1698_de_wit_ Poloniae_dusseldorf_DETAIL1.jpg

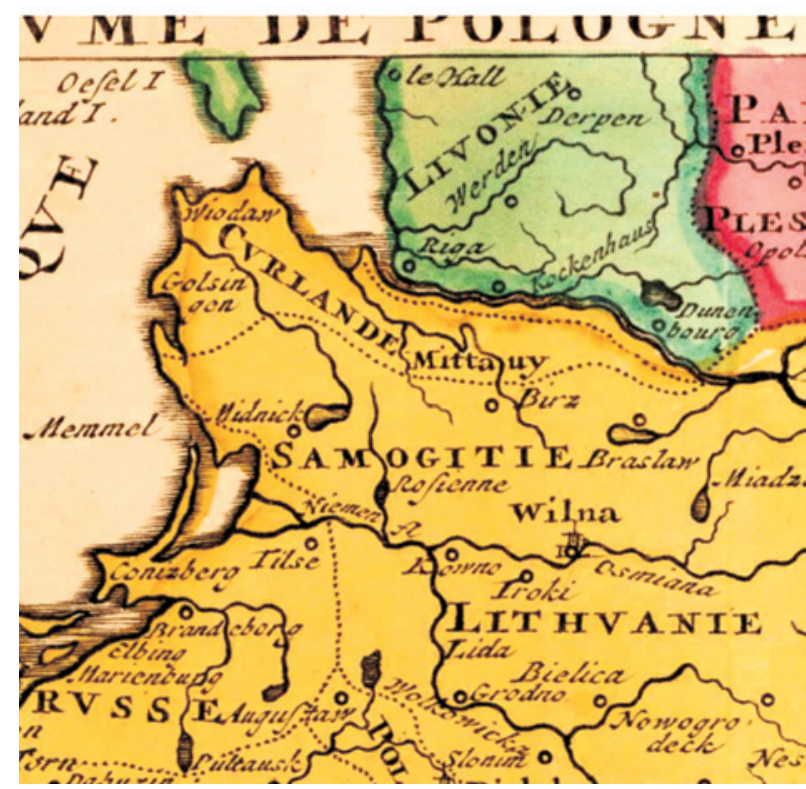

Fig. 2. Samogitia on the map of Poland by Paul de La Feuille, Amsterdam 1702

Source: http://www.lithuanianmaps.com/Maps1701-09.html

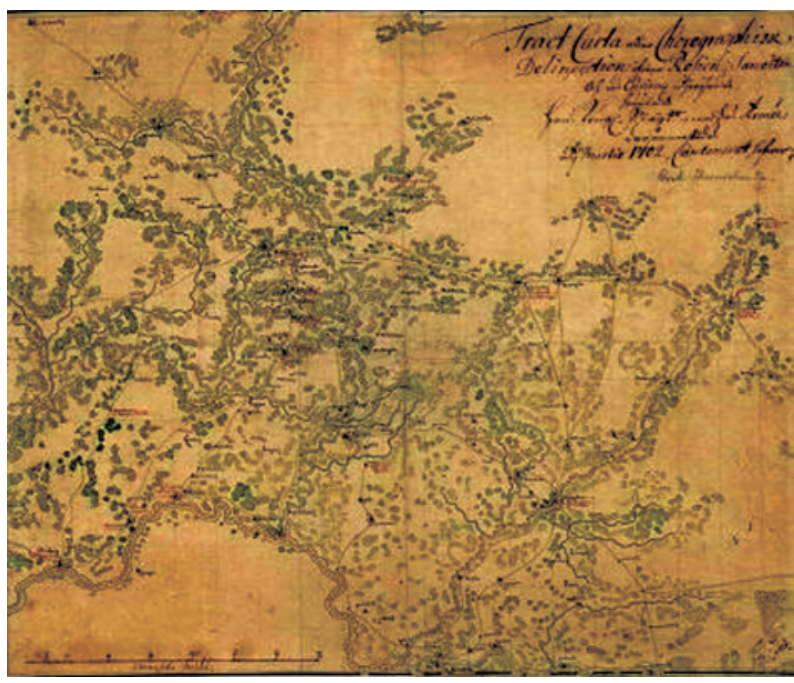

Fig. 3. Map of Samogitia by Gerhard Ernst Ehrenschantz, 1702 Source: http://www.ldm.lt/TDM/Svedu_veliavu_paroda.htm approached its natural conditions, the geographical position of the Nemunas River lower-reaches was defined more precisely (Chomskis 1958).

In Fig. 1 Samogitia on the map of Poland and Grand Duchy of Lithuania by Frederick de Witt.

Frederik de Wit(t) (1616-1698) established his printing office in Amsterdam 1648 and published several atlases since 1670 (Atlas, Atlas Minor, Atlas Maior, a sea atlas and a Belgium atlas). Besides atlases, he has published 124 land maps and 27 sea maps on separate sheets. His son and grandson of the same name produced 130 maps in total, too. The Wits' firm was shut down in 1706 and its plates passed into the ownership of Pieter Mortier (1661-1711), a geographer, copper engraver, printer and publisher from Amsterdam, who has also published the present map. After Mortier's death the firm passed into the ownership of Jean Covens ja Cornielle Mortier who named the firm Covens \& Mortier.

In Fig. 2 Samogitia on the map of Poland by Paul de LaFeuille: "Le Royaume de Pologne avec ses confins", 1702 Amsterdam, from "Atlas Portatif". In this map Samogitia is not separated from Lithuania. In the area of Samogitia is marked Varniai (Midnick), Biržai (Birz), Raseiniai (Rosennie) and several rivers.

Paul de La Feuille (1688-1727) There are currently no comments on this author. He is a son of Daniel de La Feuille Paul followed the tradition of engraving small format maps. Together with brother Jacob He published his masterpiece in 1692 "Devises et Emblems", a collection of symbols, allegories and designs mostly likely intended as templates for silversmiths, engravers, and watchmakers. He continued his father cartographic work and published numerous individual maps and atlases.

The most interesting appears to be the map of Samogitia dated 1702 , by a Swedish cartographer (Fig. 3). It was exhibited in the National Museum of Lithuania. The exhibition was prepared by the Swedish Kingdom's Embassy in Lithuania and called "The Flags and Maps of the Grand Duchy of Lithuania”. The map covers the area, where the Swedish army was deployed in 1701-1702 and it almost coincides with the zone of activities of the Swedish Military forces in 1701, December. The map depicts the lands, which belong to Šiauliai and Panevėžys regions, almost entire Kelmès region, a greater part of Jurbarkas region, entire regions of Raseiniai and Kedainiai and northern part of Kaunas region (Lietuvos... 2006).

Gerhard Ernst Ehrenschantz (1663-1703) was a lieutenant - general, fortification expert and the 
one responsible for the Swedish king Carol XII Army maintenance.

In Fig. 4 Samogitia on the large, original map of Poland, Lithuania, Ukraine, Belarus, by Guillaume de lIsle: (La Pologne... Paris: "Chez l'Auteur sur le Quai de l'Horlage a la Courone de Diamans...Et se trouve a Amsterdam chez Louis Renard Libraire prez de la Bourse"). This is rare second state of this important map.

The author's address has changed to "le Quai de l'Horlage a la Courone de Diamans", which he occupied only in 1707 and the the first couple of months of 1708 . The commercial relationship between de l'Isle and Louis Renard in Amsterdam was negotiated in 1706 , and probably did not warrant the inscription found here "Et se trouve a Amsterdam chez Louis Renard Libraire prez de la Bourse", before 1707. So one can date this map 1707 with some confidence. The relationship between de l'Isle and Renard was strained from the beginning and was never a success, but it was not terminated formally until 1718. Depicts Poland, Lithuania, Ukraine, Belarus. Of note, Poland has been divided into "Petitie Pologne" and "Grande Pologne". Also depicted is part of the Baltic Sea.

Guillaume Delisle (L'Isle, G.) (1675-1726) was a French cartographer who lived in Paris. Guillaume Delisle's first works were "The Map of the World" and "The Map of the Continents", both published in 1700.

These and the terrestrial maps produced subsequently, which surpassed all similar publications, established the son's fame. His 1718 map, Carte de la Louisiane et du Cours du Mississipi was the first detailed map of the interior of what is now the United States. It was based on the early expeditions of the French explorer Bourgmont. He prepared about 100 maps and wrote on mensuration and ancient geography. In 1718 he was the first to become chief geographer to the king.

In Fig. 5 Samogitia is presented in the map of Poland, Lithuania and Pomerania. Map dedicated to Frederick Augustus II the Strong. Contributor: Regins; Publisher: Peter Schenk, Amsterdam (Friderico Augusto vere Augusto Polon. Lithuan. Borus. Pomer. regi. duci. principi...). Map was published in the atlas: Atlas contractus sive Mapparum Geographicarum Sansoniarum auctarum et correctarum Nova Congeris, Amstelodami in 1709. Area of Samogitia on this map by dotted lines and colors very cleary differentiated from Lithuania.

In Fig. 6 Samogitia on the map of Livonia and Curland by Frederick de Witt. In the very colorful map fragment in the area northern part of Samogitia is marked major rivers, forests, very exceptionally marked Platelių Lake and city Šiauliai (Szawle Gross Schaulen).

In Fig. 7 Samogitia is presented in the stunning c. 1710 map of the Baltic coast consisting of northern Poland, Konigsburg and parts of Lithuania, by the Nurmburg cartographer J. B. Homann.

In the area of Samogitia we can see mountains and forests are rendered in profile following Homann's typical stylistic conventions. The map was engraved by J. B. Homann and printed in Nuremburg, Germany.

In Fig. 8 cutout from the beautifully detailed c. 1730 J. B. Homann map of Scandinavia. Depicts both

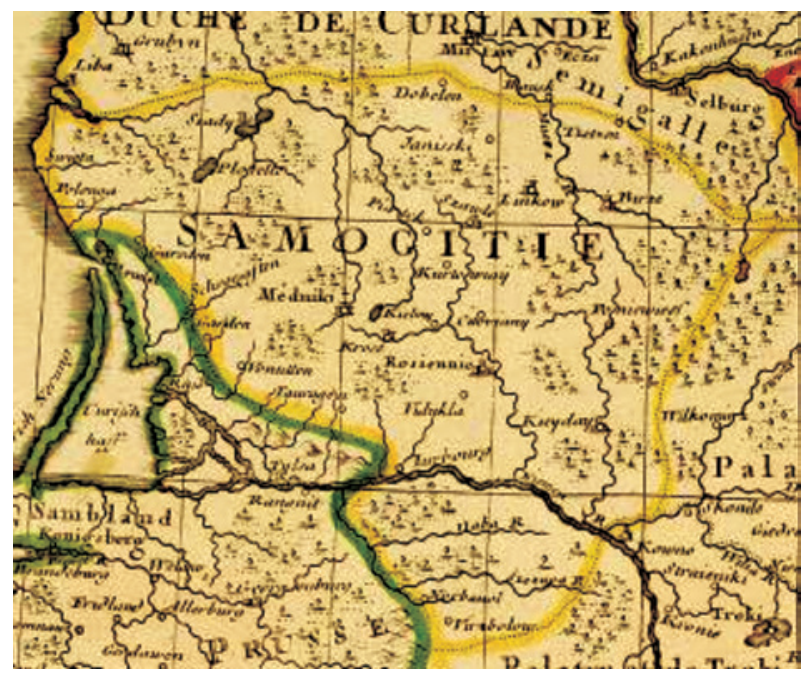

Fig. 4. Samogitia in the map of Poland, Lithuania, Belarus and part of Ukraine by L'ISLE, G. de. 1707

Source: http://www.ebay.com/itm/1707-de-lIsle-La-PologneMap-of-Poland-Lithuania-Ukraine-Belarus-/200909232969?nm $\mathrm{a}=$ true\&si=dQDyTM0rhSJf9QtLhRNhtaGoVK4\%253D\&orig cvip=true\&rt=nc\&_trksid=p2047675.12557\#ht_12070wt_1006

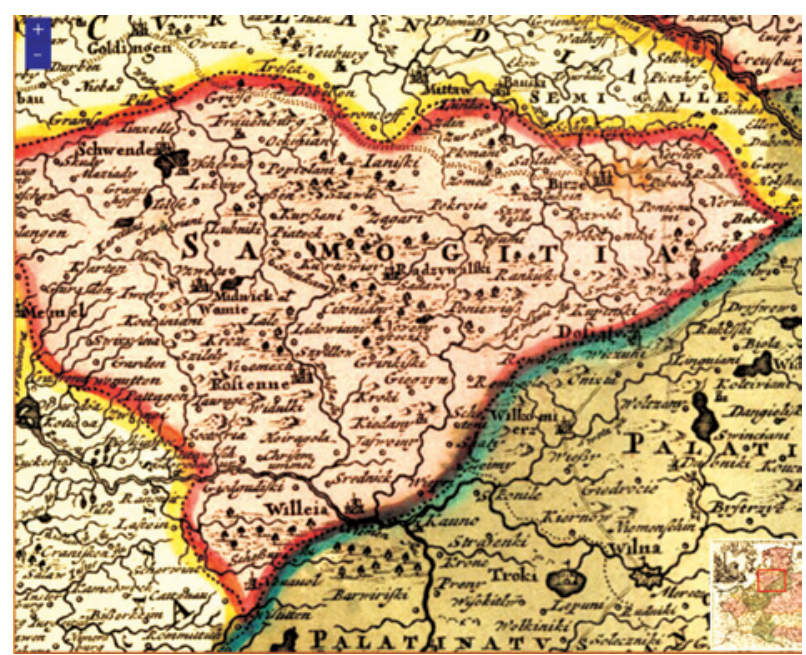

Fig. 5. Samogitia on the map of Poland, Lithuania and Pomerania by Peter Schenk, Amsterdam 1709

Source: http://www.vobam.se/bildtemp/39798.jpg 
Denmark, Norway, Sweden, Finland and the Baltic states of Livonia, Latvia and Curlandia. Title: Scandinavia complectens Sueciae Daniae \& Norvegiae Regna ex Tabulis Joh. Bapt Homanni Norimbergae.

In the area of Samogitia map notes cities, villages, roads, bridges, forests, and topography. Map printed in

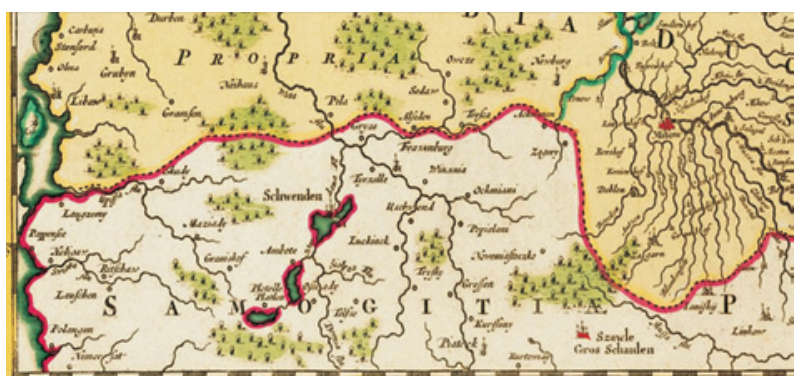

Fig. 6. Samogitia on the map of Livonia and Curland by Frederick. de Witt, Amsterdam 1710

Source: http://www.nlib.ee/html/digi/maps/mliiv18-eng.html

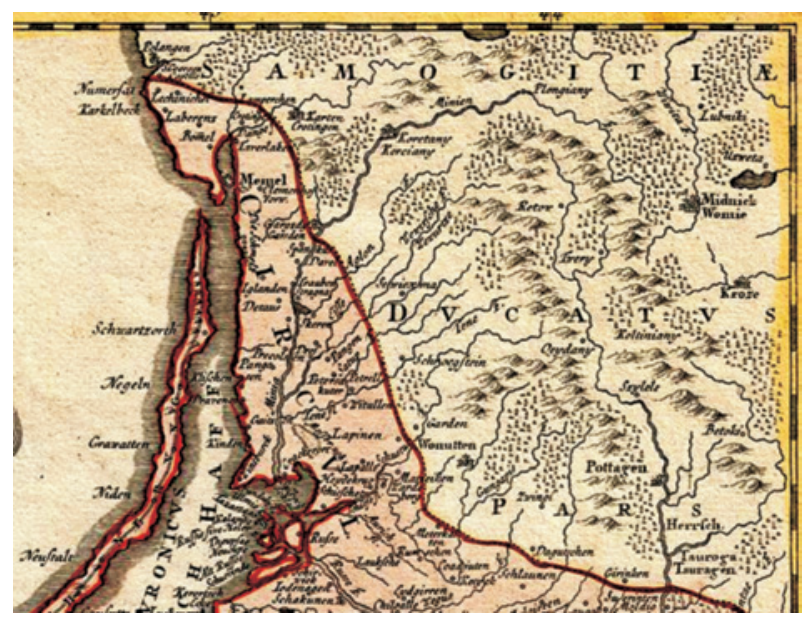

Fig. 7. Samogitia in the map of Northern Poland, Konigsburg, and Lithuania, by Johann Baptist Homann, Nuremburg 1710

Source: http://www.geographicus.com/P/AntiqueMap/Borussiae-homann-1701

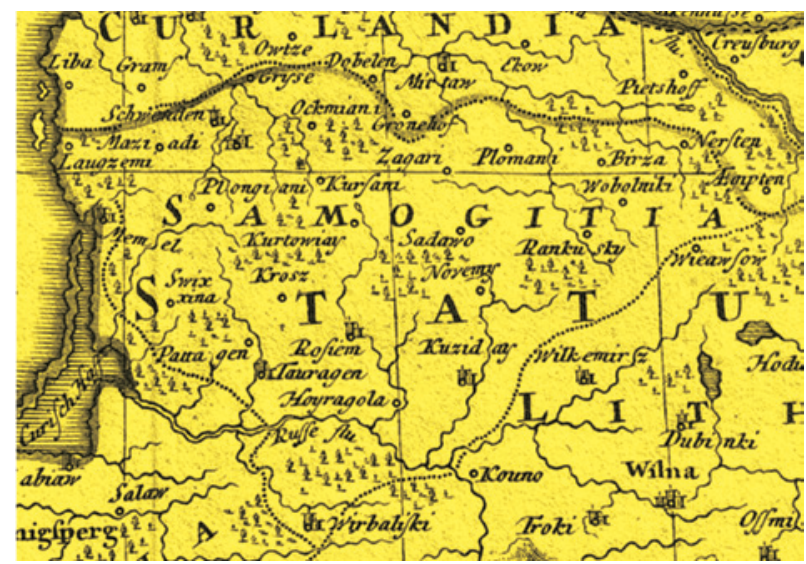

Fig. 8. Samogitia in the map of Scandinavia: Norway, Sweden, Denmark, Finland and the Baltics by Johann Baptist Homann, Nuremburg 1730

Source: http://www.geographicus.com/P/AntiqueMap/Scandinavia-homann-1730
Nuremburg. This map must have been engraved before 1715 when Homann was appointed Geographer to the King. The map does not have the cum privilegio (with privilege; i.e. copyright authority given by the Emperor) as part of the title, however it was included in the c. 1750 Homann Heirs Maior Atlas Scholasticus ex Triginta Sex Generalibus et Specialibus as well as in Homann's Grosser Atlas.

Johann Baptist Homann (1664-1724) was a German geographer and cartographer, who made maps of the Americas. Homann was born in Oberkammlach near Kammlach, which is now in Bavaria. Although educated at a Jesuit school, he eventually converted to Protestantism. In 1715 Homann was appointed Imperial Geographer of the Holy Roman Empire. Giving such privileges to individuals was an added right that the Holy Roman Emperor enjoyed. In the same year he was also named a member of the Prussian Academy of Sciences. Of particular significance to cartography were the imperial printing privileges (Latin privilegia impressoria). These protected for a time the authors in all scientific fields such as printers, copper engravers, map makers and publishers. They were also very important as recommendation for potential customers. In 1716 Homann published his masterpiece Grosser Atlas ueber die ganze Welt (Grand Atlas of all the World).

Homann died in Nuremberg. He was succeeded by the Homann heirs company, in business until 1848, known as "Homann Erben", "Homanniani Heredes", "Heritiers de Homann" abroad.

In Fig 9 Samogitia on the an extraordinary map of Poland ( Nouvelle Carte du Royaume de Pologne Divisee Selon ses Palatinats et ses Provinces, avec des Remarques Historiques pour L'Intelligence de l'His-

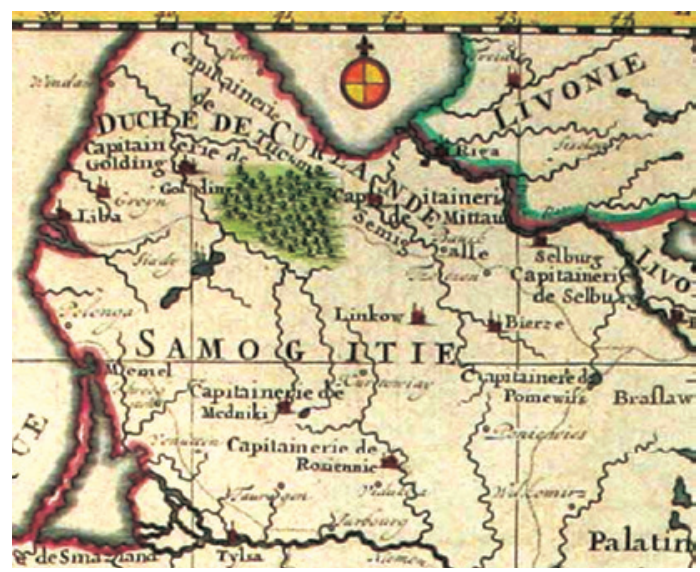

Fig. 9. Samogitia on the map of Kingdom of Poland by Henri Chatelain, Paris 1719 (In Franch)

Source: http://www.themaphouse.com/search_getamap.aspx?id= 5579\&ref=POL 880 
toire) issued c. 1710 by Henri Chatelain. Centered on ,Petite Pologne,' the map covers from the Baltic Sea to Transylvania and from Glatz to the border with Moscovie (Russia). Like most of Chatelains work it is beautifully engraved and masterfully printed on fine paper using an intense dark ink. This striking effect beautifully illustrates Samogitia with forests and mountains appearing in profile. Important cities are identified throughout as are lesser cities, castles, and waterways.

Without a doubt one of the most beautiful 18th century atlas maps of Poland, this chart was issued in volume 4 of Chatelain's Atlas Historique.

Henri Abraham Chatelain (1684-1743) was a Huguenot pastor of Parisian origins. He lived consecutively in Paris, St. Martins, London (c. 1710), The Hague (c. 1721) and Amsterdam (c. 1728). He is best known as a Dutch cartographer and more specifically for his cartographic contribution in the seminal seven volume Atlas Historique, published in Amsterdam between 1705 and 1720. Innovative for its time, the Atlas Historique combined fine engraving and artwork with scholarly studies of geography, history, ethnology, heraldry, and cosmography. Some scholarship suggests that the Atlas Historique was not exclusively compiled by Henri Chatelain, as is commonly believed, but rather was a family enterprise involving Henri, his father Zacharie and his brother, also Zacharie.

In Fig. 10 we present Samogitia on the scarce and handsomely engraved map of the Polish-Lithuanian Commonwealth and surrounding regions compiled by the distinguished Royal Geographer Georg Matthäus Seutter. This is the first state of the map (a second state in 1728 added letters to the scales in borders) and as such is a particularly fine, strong impression. Seutter based the cartography on Frederik de Wit's 1670 map of the region which was also the basis for a map issued by Homann in 1705-both Homann and Seutter's map are de facto close copies of De Wit with regard to the cartography. Stretching from St. Petersburg to the Black Sea and Stockholm to Vienna, the map covers a broad range of territory but still presents a wealth of detail including charming pictorial topography.

The map includes Samogitia and Curlandia as the lands of Lithuanian Duchy. The western border reaches the Baltic sea, the very northern point being the southern bank of Liepoja Lake. Amongst other settlements Raseiniai (Rosienne), Biržai (Birze), Kèdainiai (Kiedany) and Radviliškis (Radzivill) are most outstanding.

Seutter, Matthäus (The Elder): 1678-1757, born and died in Augsburg. Seutter was an engraver, globe- maker and publisher. In 1697 he went to Nuremberg and apprenticed as an engraver to Johann Baptist Homann. Ten years later he returned to Augsburg to establish his own map publishing house, which became a primary competitor to Homann. Most of Seutter's maps were copies of earlier work done by the Homann and Delisle firms - only about 40 were based on original work. Seutter's large folio maps are known for their bold engraving style and flamboyant cartouches and this map certainly has both on extravagant display. On his death the business was carried on by Tobias ConradLotter, his son-in-law and a master engraver for the firm.

In Fig. 11 Samogitia on the map of the Grand Duchy of Lithuania (Reiner et Josua Ottens. Magni Ducatus Lithuaniae in suos palotinatus et districtus divisus delineatus...) by Reiner Ottens.

Reiner Ottens (1698-1750) and his brother Joshua (1663-1765) Ottens have been active in map

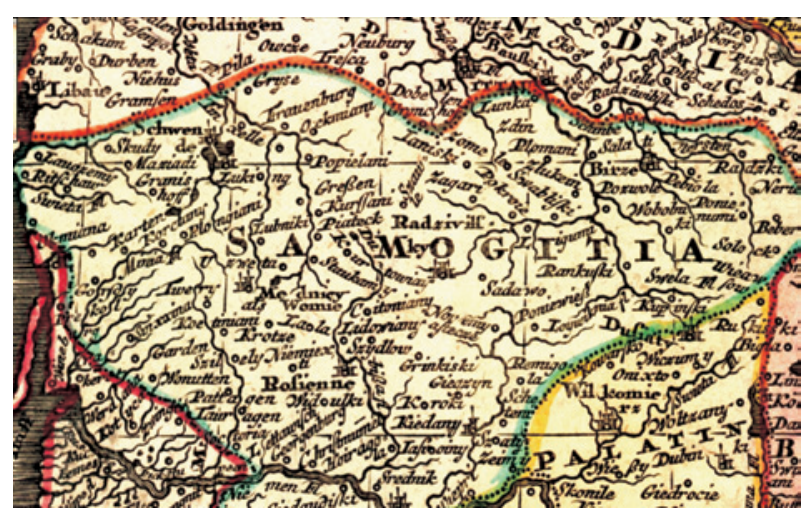

Fig. 10. Samogitia on the map of Poland - Lithuania by Matthaus Seutter, Augsburg 1720

Source: http://www.ebay.com/itm/ws/eBayISAPI.dll?ViewItem \&item $=251204168638$ \&item $=251204168638$ \&vectorid $=229466$

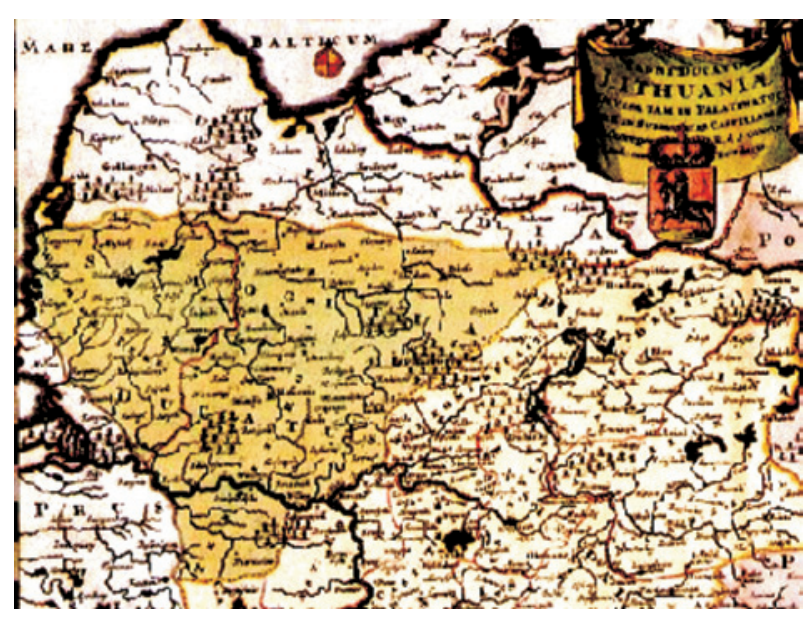

Fig. 11. Samogitia on the map of the Grand Duchy of Lithuania by Ottens R., Niuremberg 1735

Source: http://www.samogit.lt/zemaitija.en.htm 


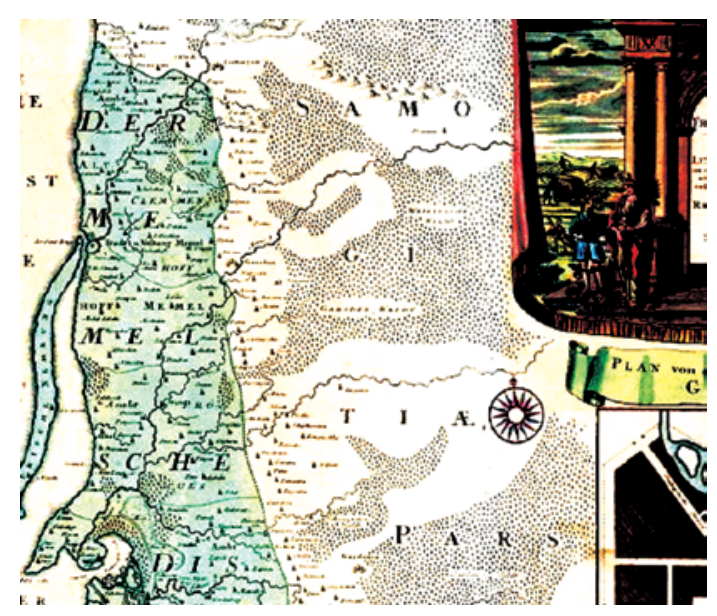

Fig. 12. Samogitia on the map of- Borussia - Lithuania Russia by Homann Heirs, Nuremberg 1735

Source: http://www.iscra.nl/E2370,map,russia,borussia,lithu ania,potentissimo_borussorum_regni_friderico_wilhelm0_ maiestate,homann.htm

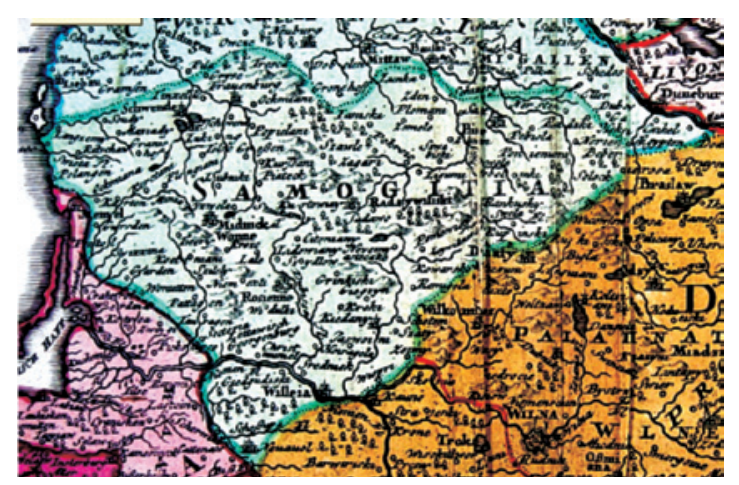

Fig. 13. Samogitia on the map of Poland and Lithuania by Johann Baptist Homann, 1739

Source: http://www.ebay.co.uk/itm/1739-Homann-antiquehand-coloured-map-of-Poland-and-Lithuania-Belarus-Ukraine-/380595104277?nma=true\&si=jJiMElMR9Z2BTXHEjHdn JXElBZU\%253D\&orig_cvip=true\&rt=nc\&_trksid=p2047675. 12557\#ht_4177wt_1086

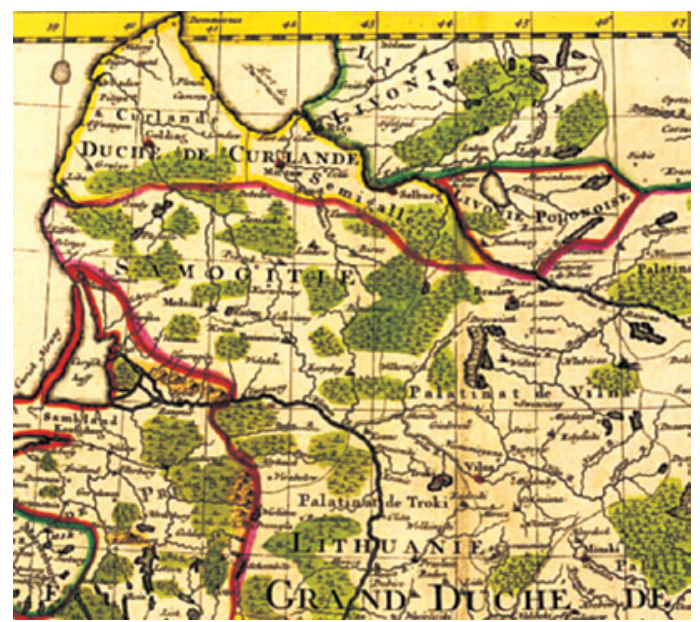

Fig. 14. Samogitia on the map of Poland and Grand Duchy of Lithuania by Guillaume Delise, 1742

Source: http://www.karty.by/wp-content/uploads/2011/01/lapologne1.jpg printing and selling during the first half of 18th Century. The family business was founded by their father Joachim, but most productive during the time of Reiner and Joshua. Joachim, the founder of the firm, was initially employed as a copperplate engraver by Frederick de Wit. In 1711 Joachim founded his own firm. Though Joachim died only a few years later, his sons Renier and Joshua took over the firm and presided over its most prolific period. The Ottens family's most notable contribution to cartography were its enormous made-to-order multi-volume atlases such as the Atlas maior cvm generales omnivm totius orbis regnorvm, Amsterdam, 1729. This atlas is a seven-volume compendium of assembled-to-order star charts and geographical maps. Some examples of the Atlas are compiled from over 800 separately issued maps.

In Fig. 12 Samogitia is shown in the map Borussia-Lithuania-Russia by Homann Heirs (Potentissimo Borussorum Regi Friderico Wilhelmo Maiestate, Fortitudine Clementia Augustissimo Hancce Maiestate, Fortitudine Clementia Augustissimo Hancce Lithuaniam Borussicam: in qua luca coloniis Salisburg., ad incolendum Regio nutu concessa chorographice exhibentur D. D. D. Regiae Suae Maiestatis). A set of 2 original antique maps that can be joined together to one very large 2-sheet map of an area of Lithuania and Eastern Prussia (Russian province of Kaliningrad) stretching from Klaipeda (Memel) in the north to Goldap in the south (a town on the Polish - Russian (Kaliningrad) border, Tilsit (Sovetsk) and Gumbinnen (Gusev). This detailed map shows many towns, a dam, regions, woods, rivers, etc. and a large figurative cartouche and a plan of the city of Gumbinnen.

A very decorative sought-after set of maps with large title cartouche and detailed only the western part of Samogitia.

In Fig. 13 Samogitia on the antique hand coloured and beautifully detailed c. 1739 map of Poland and Lithuania including land of modern day of Latvia, Belorus and Ukraine by Johann Baptist Homann. The map notes fortified cities, villages, roads, bridges, forests, castles and topography of Samogitia and other countries.

In Fig. 14 Samogitia on the map of Poland and Grand Duchy of Lithuania by Guillaume Delise, 1742 from William Darton, Atlas to Walker's Geography. London: Vernor and Hood, etc., 1802.

In Fig. 15 Samogitia is shown in a new and accurate map of Poland, Lithuania \&c. Divided into its Palatinats, drawn from the best authorities, assisted by the most approved modern maps. Publisher William Innys et al., London. 


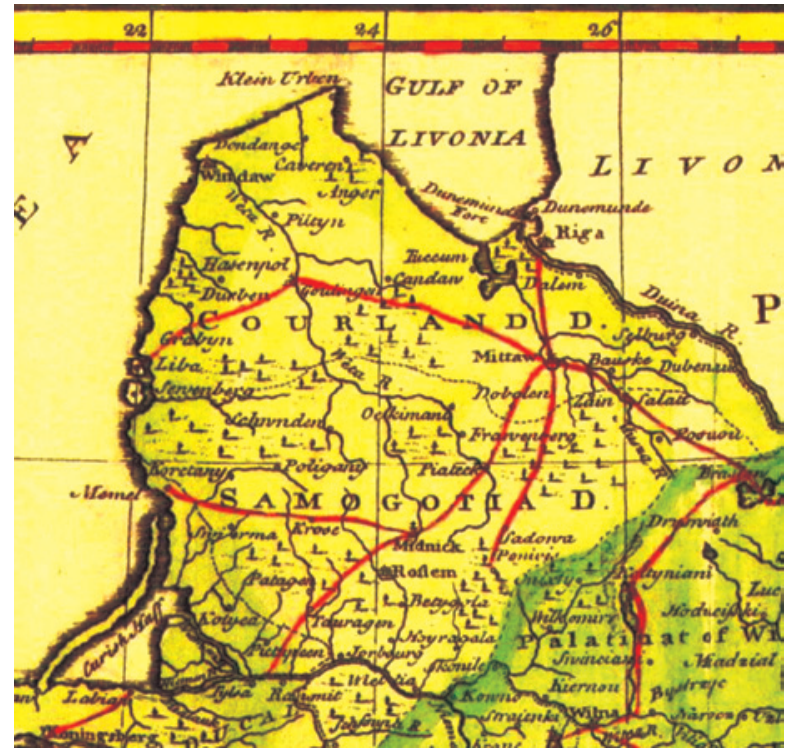

Fig. 15. Samogitia on the map of Lithuania and Poland by Emanuel Bowen, London, 1747

Source: http://www.davidrumsey.com/luna/servlet/detail/ RUMSEY 8 1 2576 270028:A-new-and-accurate-map-ofPoland,-L\#

Map being a description of the countries, islands, cities, chief towns, harbours, lakes, and rivers, mountains, mines, \&c. The whole illustrated by Emanuel Bowen, Geographer to His Majesty, being all newdrawn and ingraved according to the latest discoveries and surveys; making, of themselves, a complete atlas, for the sse of gentlemen, merchants, mariners, and others, who delight in history and geography.

The western part Samogitia on the map reaches of the Baltic Sea. This map is one of those where Samogitia shown as independent duchy Grand Duchy of Lithuania.

Emanuel Bowen (1714-1767) had the high distinction to be named Royal Mapmaker to both to King George II of England and Louis XV of France. Based in London from 1714 onwards, Bowen was highly regarded for producing some of the largest, most detailed, most accurate and most attractive maps of his era. He is known to have worked with some of the most prominent cartographic names of the period including Herman Moll, John Owen, and Thomas Kitchin. Despite his renown and success, Bowen, like many cartographers, died in poverty. Upon Emanuel Bowen's death, his cartographic work was taken over by his son, Thomas Bowen.

In Fig. 16 Samogitia on the map of the Grand Duchy of Lithuania (Magni Dvcatvs Litvaniae in svos Palatinatvs et Districtvs Divisvs Carte dv Grand Dvche de Litvaniae / delineatus a Rever. Dno. Ioanne Nieprecki Soc. Jesu) by Jean Nieprecki. The author, be-

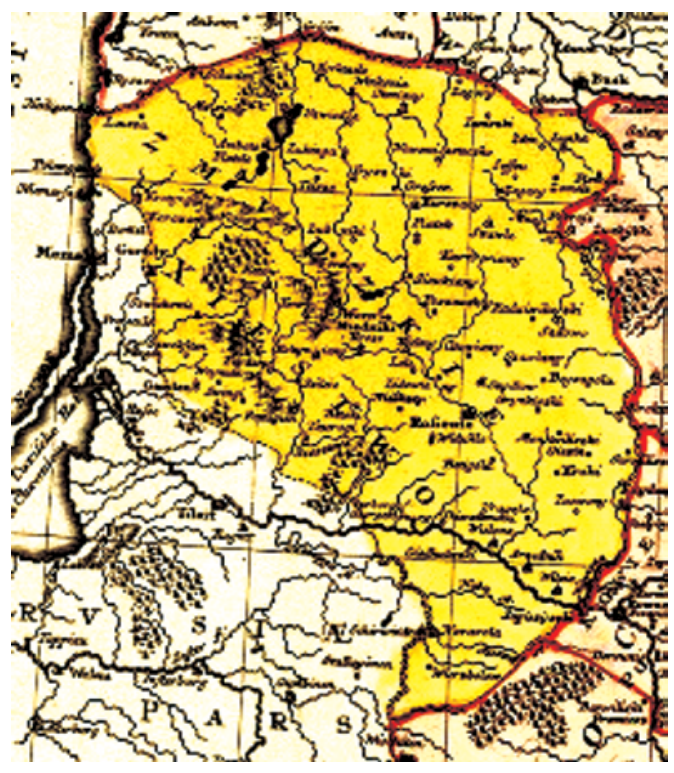

Fig. 16. Samogitia on the map of the Grand Duchy of Lithuania by J. Nieprecki, Niuremberg 1749

Sources: http://mapy.mzk.cz/mzk03/001/053/301/2619316807/; http://ausis.gf.vu.lt/mg/nr/2002/05/05nepreckis.html

ing familiar with the maps by M.K. Radziwill, N. Sanson and F. de Vitt was inspired to make a dependable map of his country, which had fewer mistakes and was more applicable for practical usage. So, the map of 1749, which was printed in Norinberg Johan Homan's family publishing house became a valuable piece of graphics, regarding its cartographical facts as well as esthetic appearance.

J. Nepracky enriched his map by solid and interesting information. He creatively with the use of special signs, i.e.crossed swords and related dates, pointed out a few places, where the Lithuanian Army during the wars with Sweden and Russia had their camps or fatal ballets.

The neighbourhood of Samogitia includes a dense net of rivers and some smaller rivers have names, the forests are depicted using silhouette drawings of trees and the settlements are grouped into four categories, depending on their political, administrative, economic and cultural importance. J. Nepriecki's map was better analysed and described by A. Samas (2002).

Jean Niepreckis (Nieprzecki) (1719-1754) from Warsaw was a teacher of mathematics and a Jesuit monk. In 1746-1750 he taught in the colleges of Polock, Gardin, Lomža and Pašiauše (Samogitia). After 1750 he moved to Warsaw and worked as a teacher in the Jesuit College there. Besides theology and liberal arts, he was also interested in geography, geodesy and cartography.

In Fig. 17 Samogitia on the old map of Poland published in 1749. Full original name of the map: 
Reise Charte durch das Königreich Polen mit allen darzu gehörigen Laendern / verfertiget von J[ohann] G[eorg] Schreibern in Leipzig.

Johann George Schreiber (1676-1745) born in Leipzig was a German engraver, cartographer and publisher. He was born 1676 and lived in Leipzig. His only work was the TAtlas Selectusy published first 1740 and reissued 1749 .

In the year 1700 was commissioned to produce a plan of the city of Bautzen, where all the houses of the city should be to see. This, later writers plan called en-

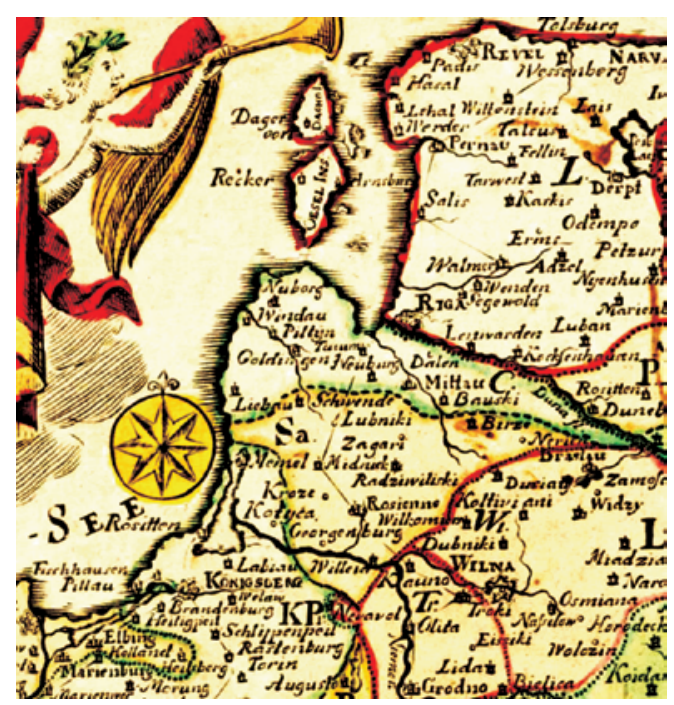

Fig. 17. Samogitia on the map of Poland by Johann Georg Schreibern, Leipzig 1749

Source: http://www.karty.by/tag/\%d1\%80\%d0\%b5\%d1\%87\% d1\%8c-\%d0\%bf\%d0\%be\%d1\%81\%d0\%bf\%d0\%be\%d0\%bb\%d 0\%b8\%d1\%82\%d0\%b0-rzech-pospolita/

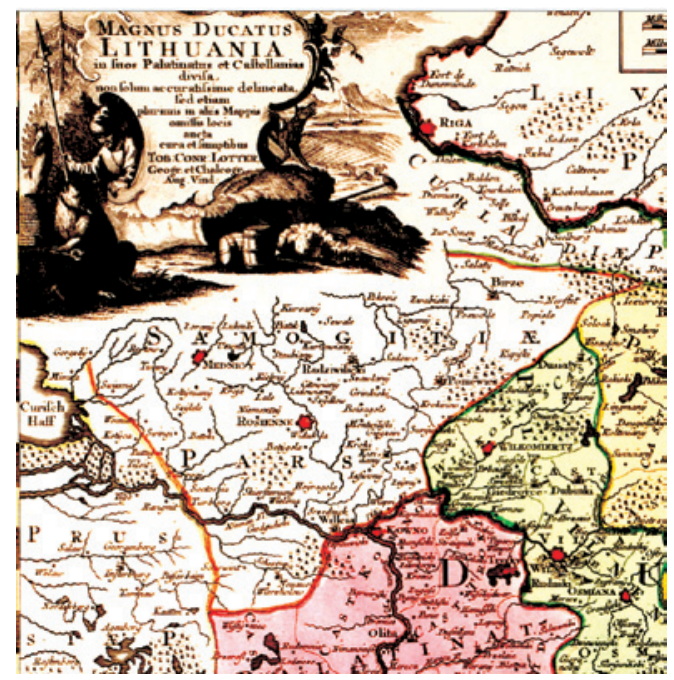

Fig. 18. Samogitia on the map of Poland and Grand Duchy of Lithuania by Tobias Lotter, 1757

Source: http://upload.wikimedia.org/wikipedia/commons/2/23/ Magnus_Ducatus_Lithuania._Вялікае_Княства_Літоўскае_ (XVIII).jpg graving was already completed by him on August 12, 1700.

Selection works: Atlas of Saxony with numerous Office maps; Atlas Selectus of all kingdoms and countries of the world, for convenient use in schools, traveling and bey reading the newspapers (1st Edition of 1740, 2nd Edition 1749); Atlas Geographicus; Engraving of Katharinenstraße 12-16 in Leipzig, 1720.

In Fig. 18 Samogitia on the maps of Grand Duchy of Lithuania ("Magnus Ducatus Lithuania in suos Palatinatus et Castellanias divisa, non solum accuratissime delineata sed etiam plurimis in aliis Mappis omissis locis aucta cura et sumptibus." "Tob: Conr: Lotter, Geogr. et Chalcogr. Aug. Vind.") by T.C. Lotter dated 1757. Map was engraved by Georg Friedrich Lotter and issued by Tobias Conrad Lotter. The map shows a very independent Samogitia. Of the several dozen settlements highlighted (in red) Varniai (Mednicy) and Raseiniai (Rosienne\}.

In Fig. 19 Samogitia on the map of Poland and Grand Duchy of Lithuania (Mappa geographica ex novissimis observationibus repraesentans Regnum Poloniae et Magnum Ducatum Lithuaniae / cura) [Tobiae Conradi Lotter]) by Tobias Lotter.

Cartographer Tobias Conrad Lotter (17171777) was a publisher of maps in Augsburg, Germany. He inherited the family mapmaking business from his father-in-law, Matthias Seutter. Lotter published atlases and numerous sheet maps, including this map of the Grand Duchy of Lithuania, becoming one of the better-known cartographers in the eighteenth-centu-

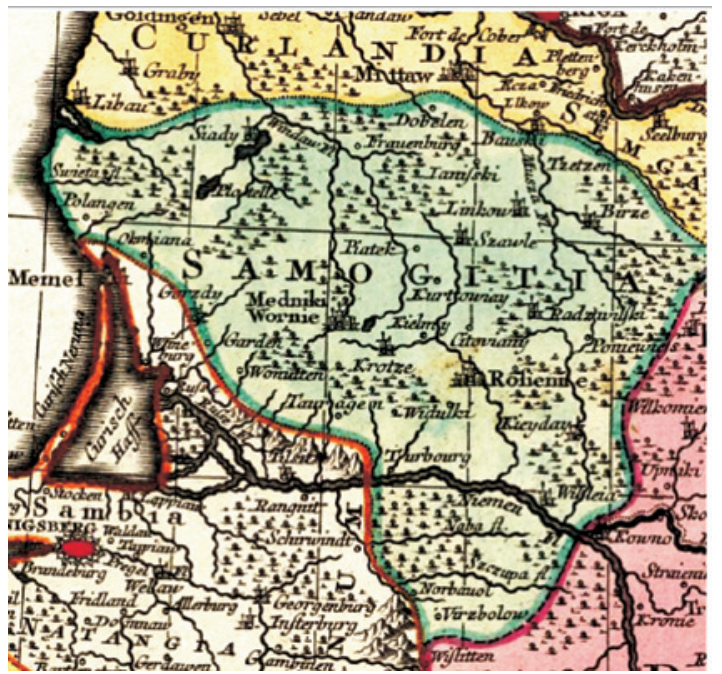

Fig. 19. Samogitia on the map of Poland and Grand Duchy of Lithuania by Tobias Lotter, Augsburg 1759

Source: http://ids.lib.harvard.edu/ids/view/8834492?buttons=y 
ry. After his death in 1777, the business was continued by his son Matthias Albrecht Lotter.

In Fig. 20 Samogitia on the map of Poland and Prussia by Jean Janvier. Original title of the map: "LES ROYAUMES DE POLOGNE ET DE PRUSSE Avec LE DUCHE DE CURLANDE...", Rare first edition: later, more common editions were published in 1774 and 1780.

Jean or Robert Janvier (1746-1776) was a Paris based cartographer active in the mid to late 18 th century. Janvier true first name is a matter of debate, as it appears as it often appears as either Jean or Robert. More commonly, Janvier simply signed his maps Signor Janvier. By the late 18th century Janvier seems to have been awarded the title of "Geographe Avec Privilege du Roi“" and this designations appears on many of his latter maps. Janvier worked with many of the most prominent French, English and Italian map publishers of his day, including Faden, Lattre, Bonne, Santini, Zannoni, Delamarche, and Desnos.

In Fig. 21 Samogitia on the map of Poland and Lithuania by Jan Jakub Kanter: Regni Poloniae, Magni Ducatus Lithuaniae...published in Nuremberg 1771 with the date of 1770 on a scale 1:675000.

Jan Jakub Kanter (1738-1786) publisher and bookseller, worked in Königsberg in the eighteenth century, developed a map of Polish probably much earlier than it has been issued, as indicated by the lack of use of materials other cartographers (Czaki, Endersch), who spent his earlier work. J. J Kanter probably developed map based on the manuscript map of the modernized by A.F. Büsching and done probably in the years 1764-1768.

\section{Maps of Samogitia in the period of first two Partitions}

In Fig. 22 Samogitia on the map of the Kingdom of Poland and the Grand Duchy of Lithuania including Samogitia and Curland divided according to their dismemberments with the Kingdom of Prussia published by W. Faden. A map from 1799 showing how the Polish-Lithuanian Commonwealth was partitioned in 1765-1795 between Prussia, Austria, and Russia. This is an extremely detailed map which lists all the cities and small towns and labels the regions according to their English names. The boundaries former Polish-Lithuanian Commonwealth colored light red.

Engraved map with small inset. Full hand col. Conformation shown pictorially and includes descriptive text with population figures. This map is excep-

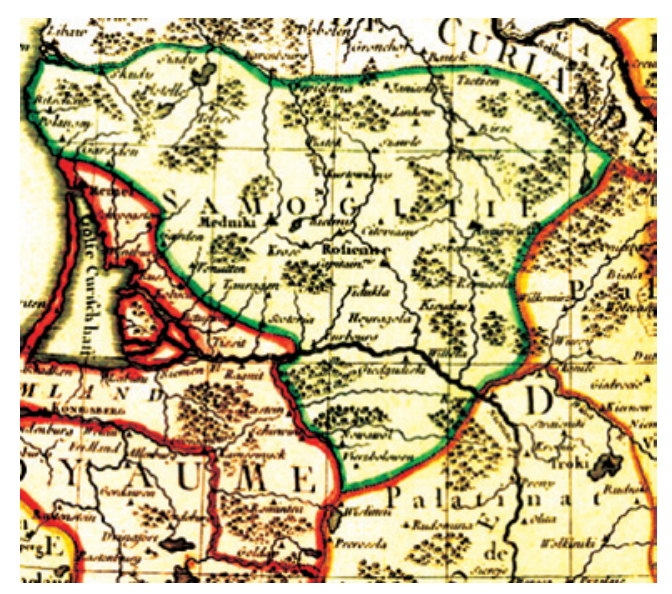

Fig. 20. Samogitia on the map of Poland and Prussia by Jean Janvier, Paris 1760

Source: http://lithuanianmaps.com/Maps1756-63.html

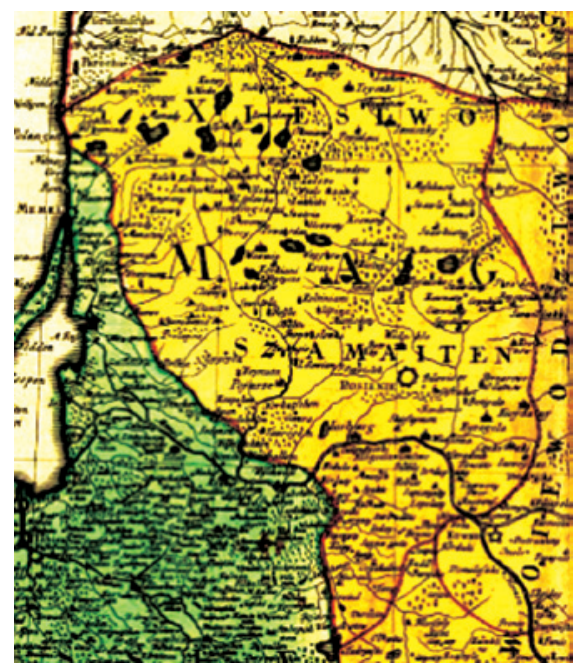

Fig. 21. Samogitia on the map of Poland and Grand Duchy of Lithuania by Jan Jakub Kanter, Niuremberg 1771

Source: http://mapy.muzeum-polskie.org/avers.html

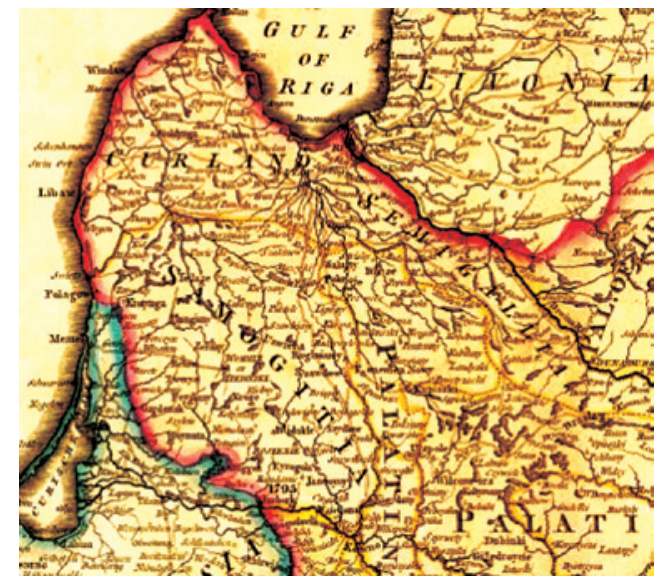

Fig. 22. Map Excerpt of Samogitia Duchy 1772-17931795 from the W. Faden's map "Kingdom of Poland and Grand Duchy of Lithuania divided according to their dismemberments" scale 1:1230000

Source: http://www.davidrumsey.com/luna/servlet/detail/ RUMSEY 8 1 24837 960045:A-map-of-the-Kingdom-of-Poland-and- 


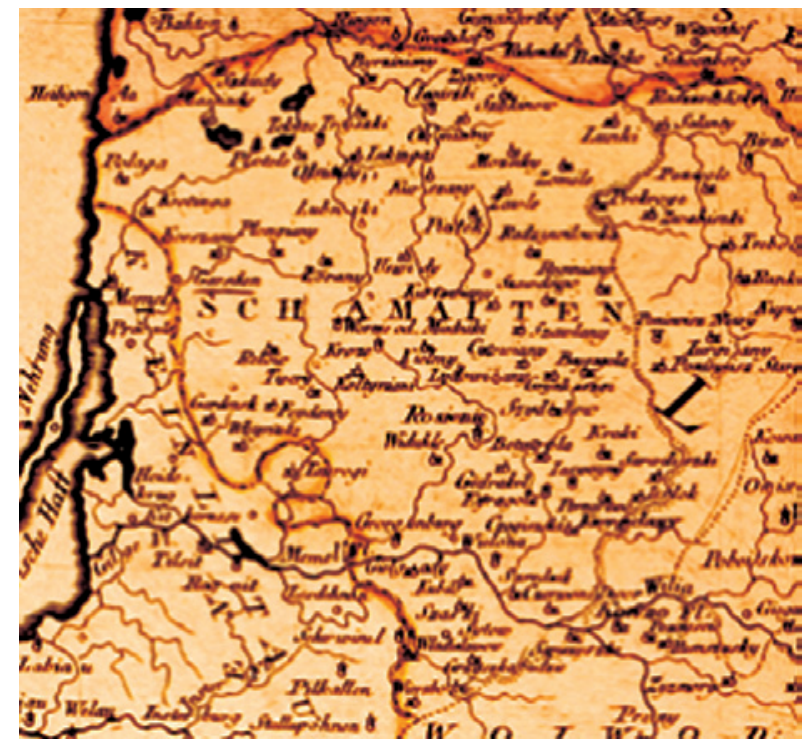

Fig. 23. Samogitia (SCHAMAITEN) on the map of Poland by Johann Walch, Augsburg 1773

Source: http://gluosnis.vu.lt/biblio/dshow?id=VUB01_355385

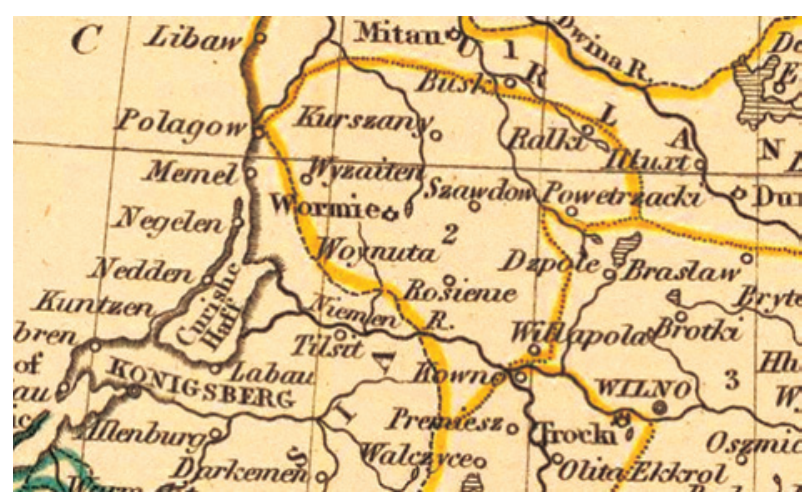

Fig. 24. Samogitia on the English map of Poland, 1772

Source: http://www.karty.by/tag/18-\%D0\%B2\%D0\%B5\% D0\%BA-18-century/page/5/

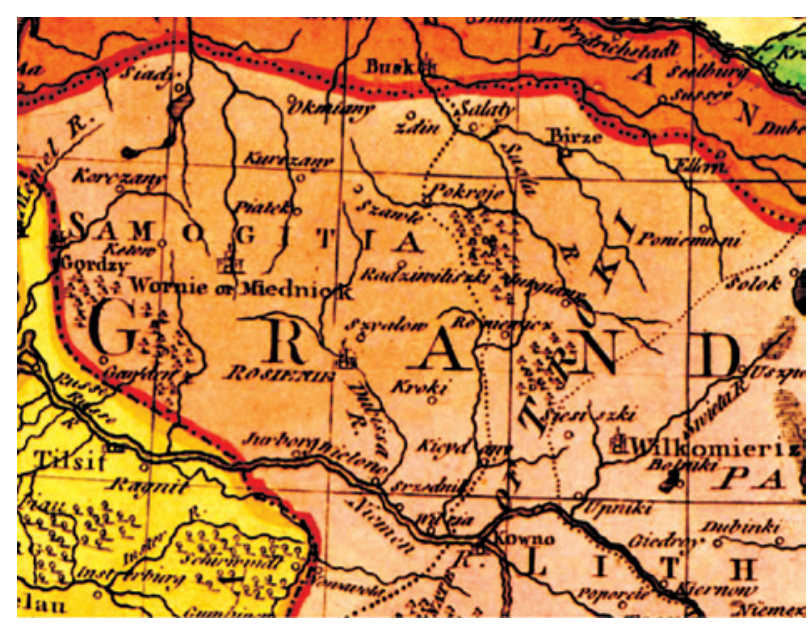

Fig. 25. Samogitia in the map of the Kingdom of Poland and the Grand Dutchy of Lithuania by Tobias Mayer, London 1772 Source: http://lithuanianmaps.com/images/c1772_mayer_poland_and_lithuania2_library_of_congress.jpg tionally detailed and it includes the main roads of the end of the $18^{\text {th }} \mathrm{c}$. as well as settlements.

William Faden (1750-1836) was an English cartographer and publisher of the late 18th century. Faden worked under the direction of Thomas Jefferys. Jefferys held the position as "Geographer to the King and to the Prince of Wales", and upon his death in 1771, this position passed to William Faden. By 1822 Faden published over 350 known maps, atlases, and military plans. Faden had a particular interest in the mapping of North America and is best known for his important publication of the North American Atlas. William Faden is also well known for his publication of the first maps for the British Ordnance Survey in 1801. Following his death in 1836 Fadens firm was taken over by James Wyld.

In Fig. 23 fragment of the map made by a German cartographer Johann Walch, engraver F. X. Hutter and included in the atlas of Johann Walch, Augsburg 1796.

It presents the political situation after the first two partitions of Polish. In the frame scaling legend: “Grenze Polens vor dem Jahr 1773", scale 1:2100 000".

Fig. 24 Samogitia on the English map of Poland previous to its First partition. Author not indicated in the map.

In Fig. 25 Samogitia in the map of the Kingdom of Poland and the Grand Dutchy of Lithuania by Tobias Mayer. Map emphasizes that the Samogitia belonged to Lithuania and its an administrative territorial unit,

Johann Tobias Mayer (1723-1762) German cartographer, astronomer, and physicist who improved standards of observation and navigation. He produced a map of the Moon's surface and concluded that it had no atmosphere. Mayer was born in Marbach, near Stuttgart. He learned architectural drawing and surveying and taught himself mathematics, French, Italian, and English. He published his first book, on the application of analytical methods to the solution of geometrical problems, at the age of 18. In 1746 he began work for the Homann Cartographic Bureau in Nuremberg, and he ended his career as professor at the Georg August Academy in Göttingen.

At the Homann Cartographic Bureau, Mayer drew up some 30 maps of Germany. These established exacting new standards for using geographical data in conjunction with astronomical details to determine latitudes and longitudes on Earth. To obtain some of the astronomical details, he observed lunar 
oscillations and eclipses using a telescope of his own design.

In Fig. 26 Samogitia on the map of Poland and Lithuania "Generalkarte von Polen, Litauen, und den Angrenzenden Ländern' enengraved by Hieronymus Benedicti, developed on the basis of materials RizziZannoni, GF Uz'a, JH Pfau'a and B. Folin and published in Allgemeiner Grosser Atlas, Verfasst v. D'Anville, Wien 1780-1797 F.A.Schraembl.

Engraver Hieronymus Benedicti (1756-1809). There is no more information.

In Fig. 27 Samogitia on an uncommon map which, despite the date, shows northern Lithuania after the Second Partition of the Polish-Lithuanian Commonwwealth of 1793. Map by Bartolomeo Borghio and Vincenzo Pazzinio Carlio "Il Gran Ducato di Lituania Diviso ne suoi Palatinati".

Bartolomeo Borghi (1750-1821) was an italian cartographer, engraver and publisher (editor of Atlante Geografica by Pazuzini Carli, Siena 1788/1800). B. Borghi was also associated with another atlas, Atlas Geografico, which he edited. Borghi also prepared Topographia della Città de Firenze (1817). Tooley's Dictionary of Mapmakers Revised Edition, Vol. I, p. 166. Giovanni Battista Vermiglioli (Biografia degli scrittori perugini e notizie delle opere loro, Perugia, 1828-1829). These works characterizes Borghi as one of the best geographers in Europe.

As a cartographer before his arrival in Florence he received by the Grand Duke Pietro Leopoldo many positions of scientific and economic interest, including the map of Cortona's cadastre, the map of the county near Castiglione and a project for the use of water as a motive power for irrigation in Val di Chiana.

In Fig. 28 we present Samogitia on the map of Grand Duchy of Lithuania by Franz Johann Joseph von Reilly, Wien 1789.

In Vienna, in 1792, an Atlas was printed by the publisher Franz Johann Joseph von Reilly. It also includes the map of Lithuania, consisting of four separate parts or maps. They are numbered No. 47, 48, 49 and No. 50. Samogitia is included in the map under No.: 49 "GrossherzogthumsLitauen Nordwestlicher Theil Nro.49" [North West part of the Grand Duchy of Lithuania]. The map was designed in 1789.

Austrian born Franz Johann Joseph von Reilly (1766-1820) was a Viennese art dealer who in his early twenties turned to map publishing, and between the years 1789 and 1806 produced a total of no less than 830 maps. His "Schauplatz der fünf Theile der Welt" (World Atlas) in fact covered only maps of Europe,

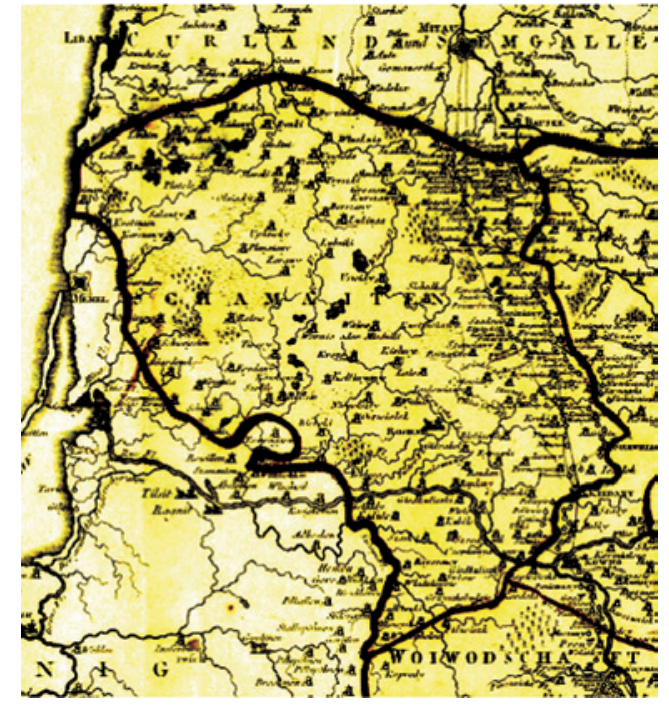

Fig. 26. Samogitia on the map Poland and Lithuania by Hieronymus Benedicti, Wien 1780

Source: http://www.zb.unibe.ch/adam/zoom/zoom.php? col=ryh\&pic=Ryh_6003_33

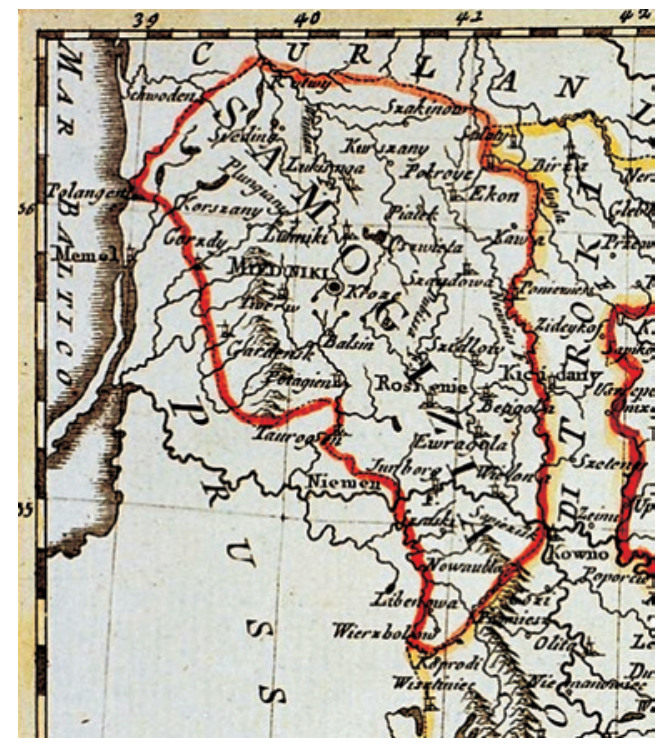

Fig. 27. Samogitia on the map of Grand Duchy of Lithuania by B. Borghi, C. V. Pazuzini, 1789

Source: http://www.leejacksonmaps.com/archive5.htm

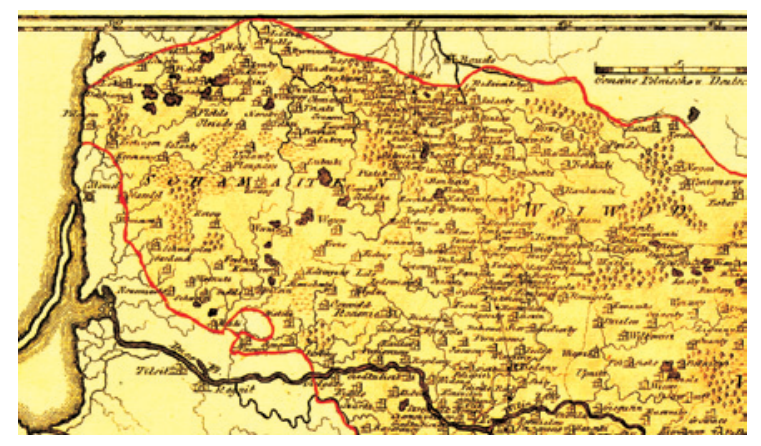

Fig. 28. Samogitia (SCHAMAITEN WOIWOD) on the map of Grand Duchy of Lithuania by Franz Johann Joseph von Reilly, Wien 1789

Source: http://lithuanianmaps.com/images/1791_von_Reilly_Litauen_49_ENTIRE_old_leaf.jpg 


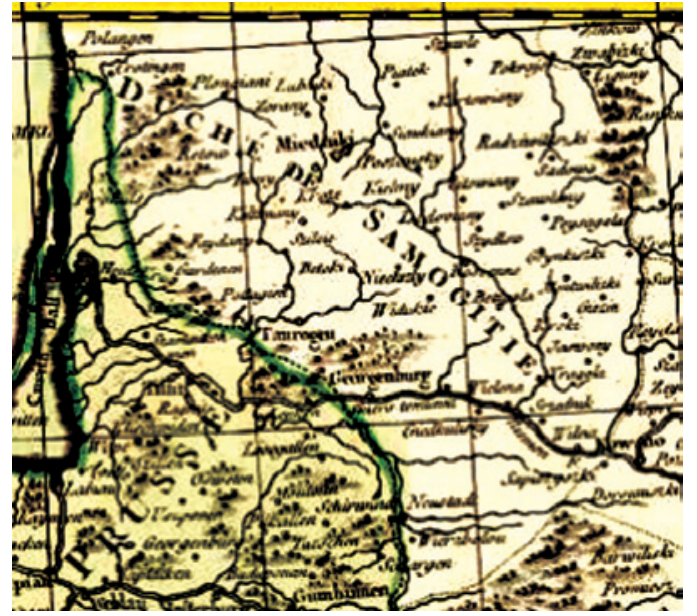

Fig. 29. Samogitia on the map of German Empire and Poland by Rizzi Zannoni, Paris 1783

Source: http://www.swaen.com/zoom.php?id=8725\&referer= item.php

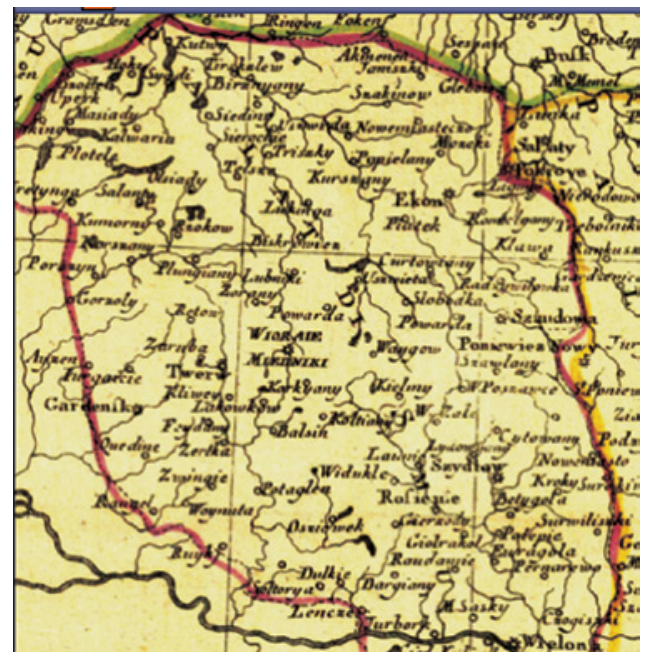

Fig. 30. Samogitia on the map of Poland by Antonio Rizzi Zannoni, Venine 1791

Source: http://www.swaen.com/antique-map-of.php?id=20549

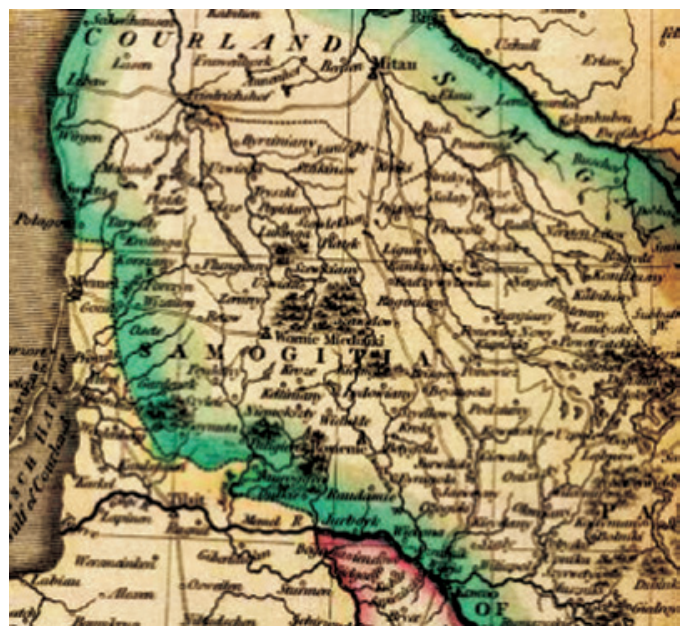

Fig. 31. Samogitia on the map of Poland and Grand Duchy of Lithuania by John Cary, London 1799

Source: http://www.davidrumsey.com/luna/servlet/detail/ RUMSEY 8 1 21529 640021:A-new-map-of-Poland,-andthe-Grand- whilst the Grosser Deutscher Atlas also included maps of other continents and was, therefore, the first World Atlas produced by an Austrian.

Reilly's "Grosser deutscher Atlas" was also notable as the first completely 'Austrian' atlas. This large world atlas, containing relatively few maps, was issued between 1794 and the end of 1796. Reilly may have used Franz Anton Schraembl's work as his model, at least in part.

In Fig. 29 Samogitia on the rare compete example of Rizzi-Zannoni's 1783 decorative four panel map of the German empire and Poland. Original Title of the map: "Carte de L'Empire D’Alemagne avec les Etats de Boheme". Rizzi-Zannoni's map covers from Jutland to the Gulf of Venice and from england to Poland. The map offers excellent detail throughout showing mountains, rivers, forests, national boundaries, regional boundaries, forts, and cities. Drawn by Rizzi-Zannoni c. 1783 for issue as plate nos. 14-17 in Jean Lattre's 1783 edition of the Atlas Moderne (Atlas Moderne ou Collection de Cartes sur Toutes les Parties du Globe Terrestre).

In Fig. 30 Samogitia on the beautifully-engraved map of Poland was published circa 1791 by Giovanni Antonio Rizzi-Zannoni as "Carte Generale de Ia Pologne."

Giovanni Antonio Bartolomeo Rizzi Zannoni (1736-1814) was a noted astronomer, surveyor and mathematician of great versatility active in Venice and Naples. Zannoni was born in Padua, Italy. Between 1749 and 1751 Zannoni studied Astronomy at the University of Padua under John Polen, a prominent astronomer of the period. After leaving the University, Zannoni was commissioned by the King of Poland, Augustus III, to map that country. His achievements included a large scale map of Poland, appointments as geographer to the Venetian Republic, and as hydrographer to the Depot de Marine in Paris. The maps in his various atlases were beautifully engraved, showing minute detail and embellished with elaborate cartouches. Rizzi Zannoni is known for his world atlas, the French edition of which was published in 1762 as Atlas Moderne by Lattré in Bordeaux.

In 1781, he was invited by the Bourbon rulers of the Kingdom of Naples to direct the Topographical Office, among the first governmental cartographic agencies in Europe. There he produced celebrated land and maritime atlases of the region, as well as many separately issued maps.

In Fig. 31 is presented a new map of Poland, and the Grand Duchy of Lithuania, shewing their dismemberments and divisions between Austria, Russia and Prussia, in 1772, 1793 and 1795, from the latest 


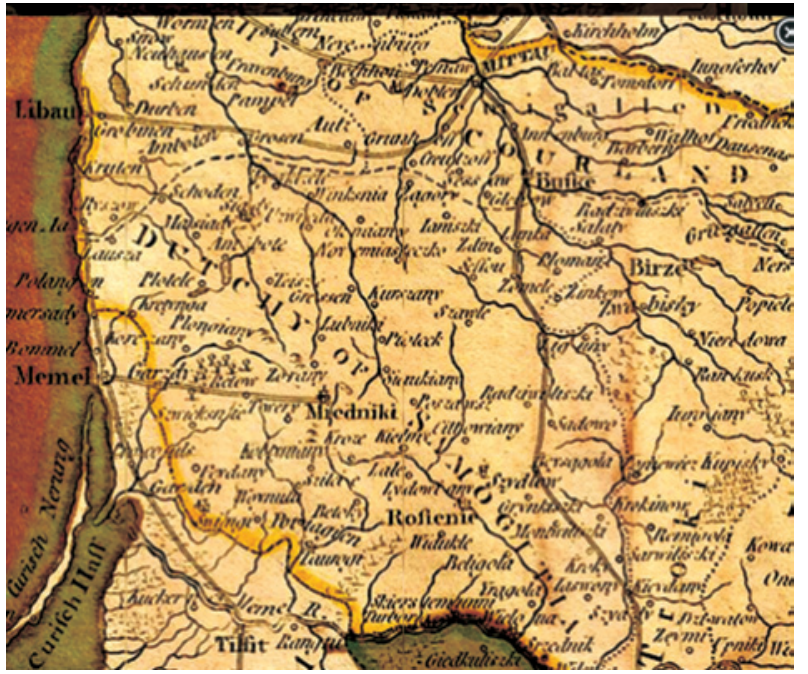

Fig. 32. Samogitia in the map of the Kingdom of Poland, with its dismembered provinces and the Kingdm of Prussia by Laurie and Whittle, 1799

Source: http://www.geographicus.com/P/AntiqueMap/PolandPrussia2-lauriewhittle-1799

authorities. By John Cary, engraver, 1799. London: Printed for J. Cary, Engraver \& Map-seller.

J. Cary's map marked the overland roads. Noteworthy that all the maps designed until the $18^{\text {th }}$ century did not include any overland roads.

In Fig. 32 Samogitia in the important 1799 map by Laurie and Whittle depicts the Kingdom of Poland following the 1795 Third Partition (A New Map of the Kingdom of Poland, with its dismembered provinces and the Kingdm. of Prususia). The map covers all Poland and the former Grand Duchy of Lithuania, parts of Prussia, Russia, Livonia, Hungary, Germany and Austria. This map depicts Poland in 1799, four years following the 1795 Third Partition of Poland. Here Russia has annexed more the entire western half of the former Polish-Lithuanian Confederation. Austria seized the lands around Lwow and Krakow while Prussia claimed the territories to the north and west of Warsaw.

Laurie and Whittle (fl. 1794-1858) were London, England, based map and atlas publishers active in the late 18 th and early 19 th century. Generally considered to be the successors to the Robert Sayer firm, Laurie and Whittle was founded by Robert Laurie (c. 1755-1836) and James Whittle (1757-1818). Robert Laurie was a skilled mezzotint engraver and is known to have worked with Robert Sayer on numerous projects. James Whittle was a well-known London socialite and print seller whose Fleet Street shop was a popular haunt for intellectual luminaries. The partnership began taking over the general management of Sayer's firm around 1787; however, they did not alter the Sayer imprint until after Sayer's death in 1794. Apparently Laurie did most of the work in managing the firm and hence his name appeared first in the „Laurie and Whittle“ imprint. Together Laurie and Whittle published numerous maps and atlases, often bringing in other important cartographers of the day, including Kitchin, Faden, Jefferys and others to update and modify their existing Sayer plates.

\section{The maps illustrating the history of Samogitia in the 19th century}

In 1795 after the third partition of the Republic, Samogitia was ceded to Russia.This period is characterized by the struggle for autonomy which then developed into a struggle for the full independence of Lithuania. The Lithuanian question which had at first arisen only within the Russian political arena gradually acquired an international character until finally the world perceived the reborn Lithuanian state.

In Fig. 33 Samogitia in the begining of the 19th century is presented on the map of Poland and Lithuania by Robert Wilkinson.

The French Invasion of Russia in 1812, also known as the Russian Campaign in France and the Patriotic War of 1812 in Russia was a turning point during the Napoleonic Wars. It reduced the French and allied invasion forces (the Grande Armée) to a tiny fraction of their initial strength and triggered a major shift in European politics as it dramatically weakened French hegemony in Europe.

In Fig, 34 Samogitia on the map "Kriegs - Theater zwischen Frankreich und Russian (1812)". Map is representative of the former territories of the Republic of Both Nations in the Napoleon wars epoch.

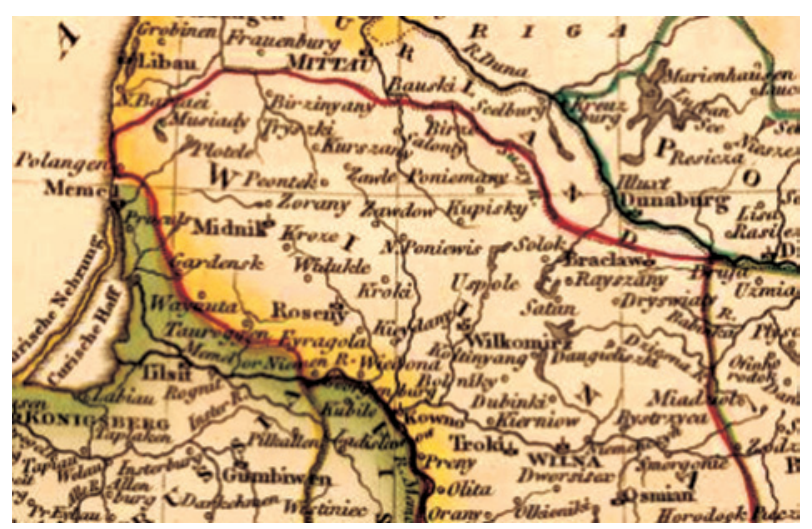

Fig. 33. Samogitia on the map of Poland and Lithuania by Robert Wilkinson, London 1808

Source: http://www.davidrumsey.com/luna/servlet/detail/ RUMSEY 8 1 241551 5512652:Poland-?qvq=w4s:/where/ Poland/Lithuania;lc:RUMSEY 8 1\&mi=7\&trs=35 


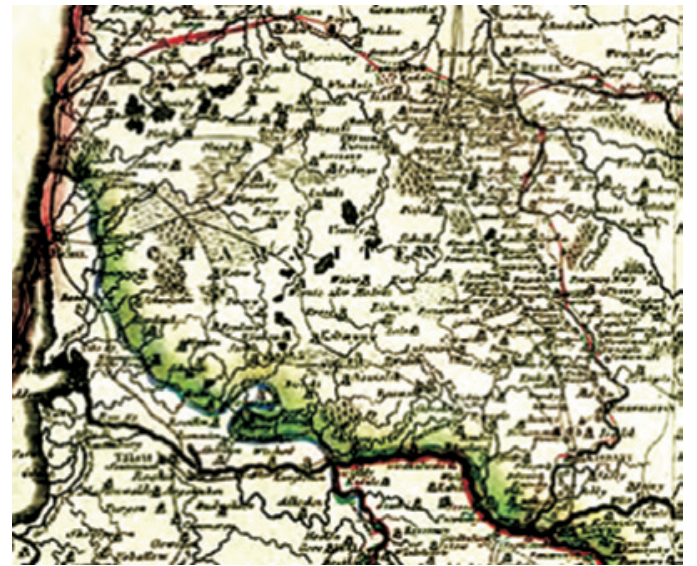

Fig. 34. Samogitia on the map "Kriegs - Theater zwischen Frankreich und Russian (1812)”. Map publisher Artaria and Co. Source: http://www.maps4u.lt/lt/includes/siuntiniai/Z/Kriegs_ Theater_1812.htm

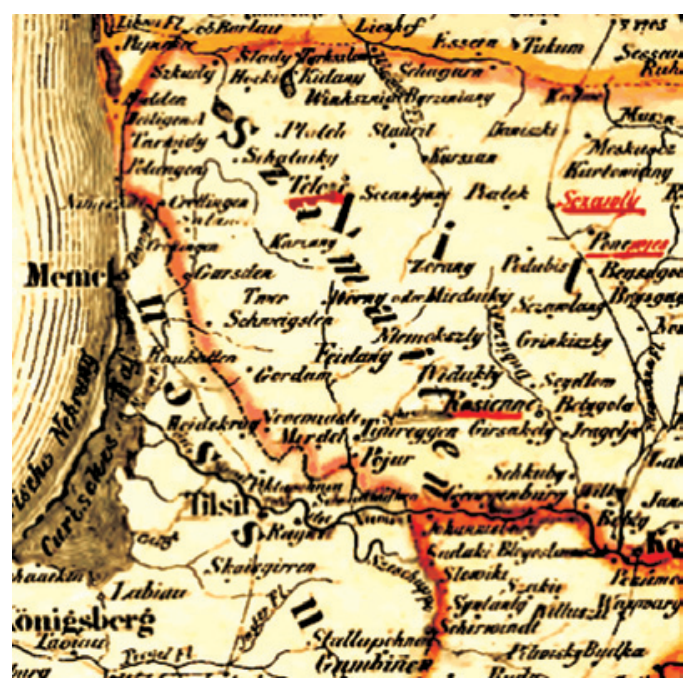

Fig. 35. Samogitia (Schamaiten) on the map of Russian provinces, Danzig 1831 list.inst.v Elbing: Rahnke Sachse \& Co. Source: http://www.karty.by/wp-content/uploads/2011/09/1831.gif

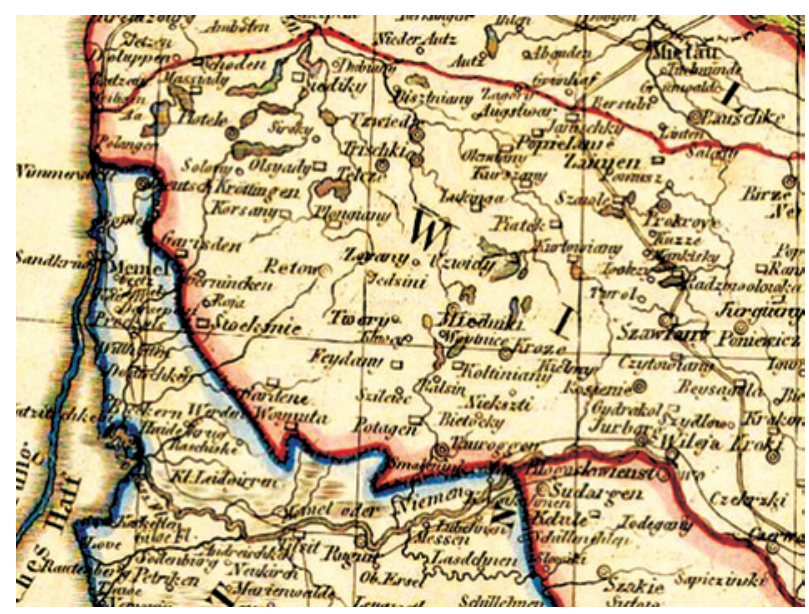

Fig. 36. Samogitia on the map of Poland and Lithuania by cousins Carlo Artaria and Francesco, Viena, 1831

Source: http://www.maps4u.lt/lt/includes/siuntiniai/Z/Kriegs_ Theater_1812.htm
Scale of the map 1:1 7000 000. Map publisher Artaria and Comp.

In Fig. 35 Samogitia on the map of Russian provinces in 1831 (Karte der Russischen Provinzen Curland, Schamaiten, Lithauen, Podleisen \&Volhynien. Order der Gouverments).

In Fig. 37 James Wyld's “A Map of the Kingdom of Poland", 1843. This map was originally published with a different title by William Faden in 1795 (Fig. 22). The map is based on the Rizzi-Zannoni 24-sheet map of 1772 that was commissioned by the King of Poland. An inset contains a bird's-eye plan of Warsaw flanked by tables of information concerning the population, religion, and languages. A color key below the title identifies the regions of Prussia, Russia, Austria and the Kingdom of Poland. Wyld, successor to William Faden, maintained the high standard of graphic and factual excellence that had been established by his predecessor and his maps are among the finest published in the early 19th century.

Cartographer James Wyld I (1790-1836) and his son James Wyld II (1812-1887) were the principles of English mapmaking dynasty active in London during much of the 19th century. The elder Wyld was a map publisher under William Faden and did considerable work on the Ordinance Survey. On Faden's retirement, the Wyld took over Faden's workshop acquiring many of his plates. Wyld's work can often be distinguished from his son's maps through his imprint, which he signed as „Successor to Faden“. Following in his father's footsteps the younger Wyld joined the Royal Cartographical Society in 1830 at the tender age of 18 . When his father died in 1836, James Wyld II was pre-

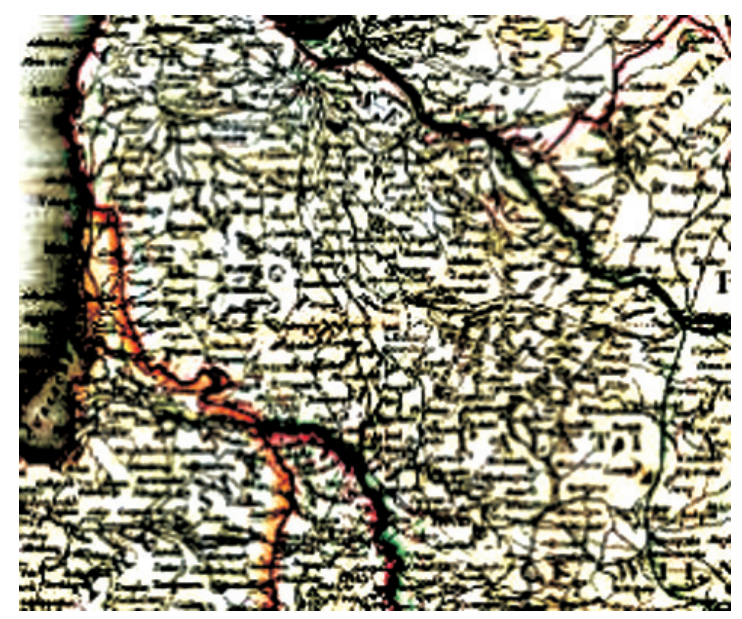

Fig. 37. Samogitia on the map of the Kingdom of Poland by James Wyld, 1843

Source: http://www.bing.com/images/search?q=map+of+Rizzi+ ZANNONI+1772\&view=detail\&id=C982B061224C1BEB92F91 EF358C3EE993CE4682B\&first=31\&FORM=IDFRIR 
pared to fully take over and expand his father's considerable cartographic enterprise. Like his father and Faden, Wyld II held the title of official Geographer to the Crown, in this case, Queen Victoria. Among his first major decisions was to move operations from William Faden's old office at Charing Cross East to a new larger space at 475 Strand. Wylde II also chose to remove Faden's name for all of his updated map plates. Wyld II continued to update and republish both his father's work and the work of William Faden well into the late 1880s. One of Wyld's most eccentric and notable achievements is his construction of a globe 20 meters in diameter in the heart of Leicester Square.

Figs 38 and 39 shows Samogitia on Karl von Spruner's maps of Poland and Lithuania in the beginning of the $13^{\text {th }}$ century and of Prussia and Livonia between 1525 and 1562.The map Fig. 37 covers territory from the Gulf of Finland and Estonia to Lithuania and Prussia.

During the early $13^{\text {th }}$ century, most of modern day Estonia, Latvia and parts of Lithuania were conquered by two German religious orders. In 1236 the Mindaugas defeated the Livonians and were crowned Kings of Lithuania, thus establishing the short-lived Kingdom of Lithuania. The whole is rendered in finely engraved detail exhibiting throughout the fine craftsmanship of the Perthes firm. Prepared by Karl Spruner for publication as plate D XII in the second edition of Justus Perthes 1854 Historich-Geographischer, Hand-Atlas zur Geschichte der Staaten europa's vom Anfang des Mittelalters bis auf die Neueste Zeit.

Karl von Spruner (1803-1892) or Spruner Karl von Merz or Spruneri was a Stuttgart born cartographer, scientist, and map publisher active in Germany during the middle part of the 19th century. Joining the Bavarian army at the tender age of 11, Spruner dedicated most of his life to military service. Spruner's superiors, recognizing his keen intellect, eventually assigned him to the army's cartographic division. Military education earned him the title of Doctor of Cartography in 1852. In 1855 he attained the rank of Lieutenant-Colonel and, in 1883, General. Cartographically, Spruner is best known for his historical atlases, most of which were published by the Justus Perthes firm. His much admired maps studiously applied historical political geographies to contemporary physical geographies. Spruner also worked with Heinrich Theodore Menke, a well-known German mapmaker, to produce and later revise his many historical maps.

Fig. 40 shows Samogitia on the map of Sweden, Poland, Lithuania, Russia, Belarus by Adolf Stieler, published in Hand Atlas Uber Alle Theile Der Erde Und

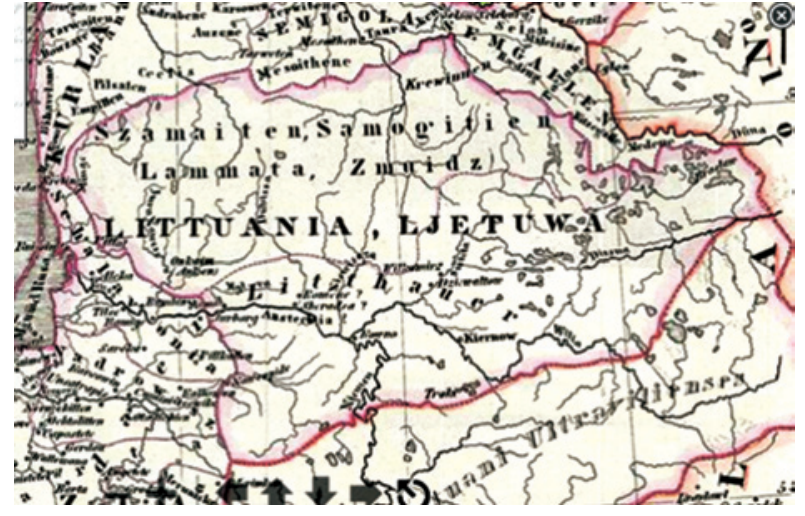

Fig. 38. Samogitia on the map of Poland and Lithuania by Karl von Spruner, 1854

Source: http://www.geographicus.com/P/AntiqueMap/BalticSeaCountrie s-spruner-1854

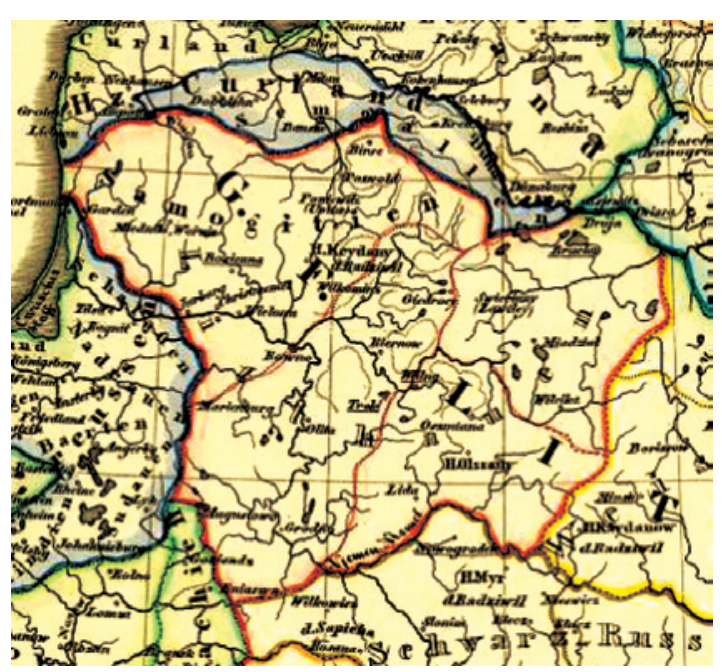

Fig. 39. Smogitia on the historical map of Poland and Lithuania (1125-1386) by Karl von Spruner, 1855

Source: Atlas: Nordische Reiche No. V. Gotha: Justhus Perthes. Rev. 1855

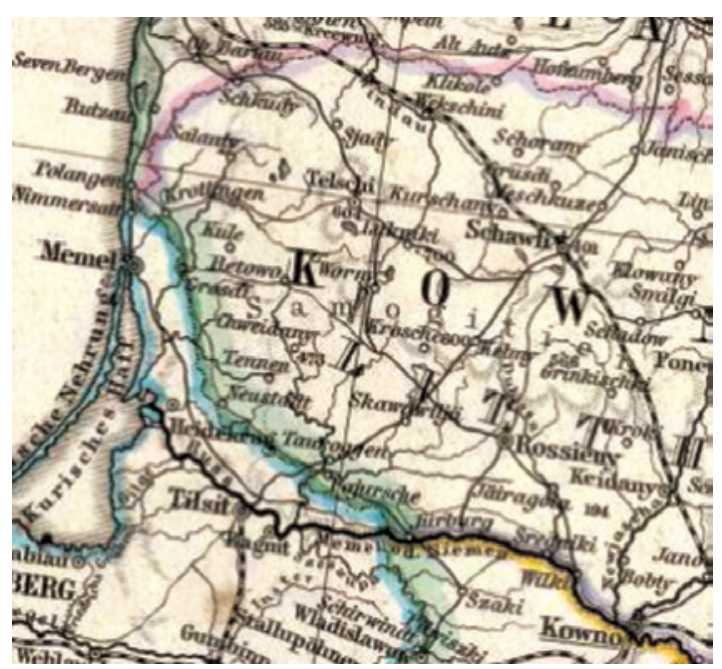

Fig. 40. Samogitia (Samogitien) on the map of Poland, Lithuania, Russia, Belarus by Adolf Stieler, 1873

Source: http://www.davidrumsey.com/luna/servlet/detail/ RUMSEY 8 1 2440 240016:Ost-Europa,-No--3--SudSchweden,-di 


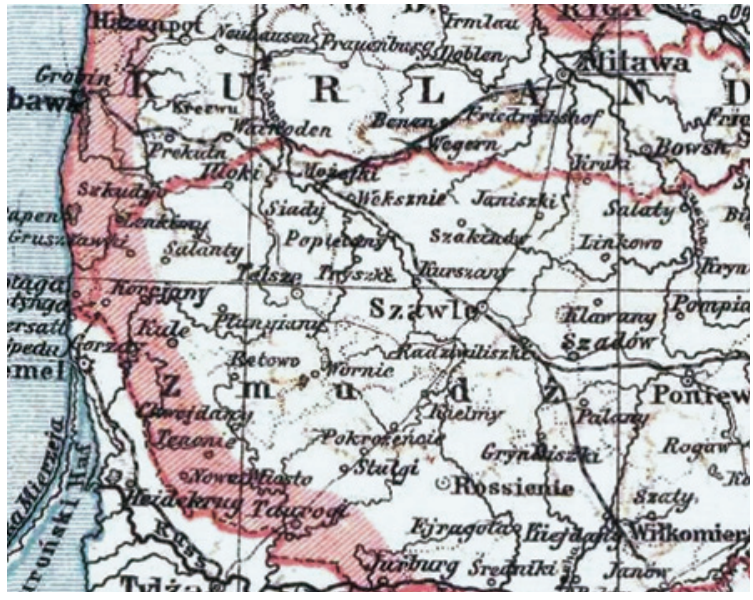

Fig. 41. Samogitia on the map of Gubernias of the Kingdom of Poland

Source: http://lithuanianmaps.com/images/1902_Gubernie_zachodnie_krolestwo_polskie_19022.jpg

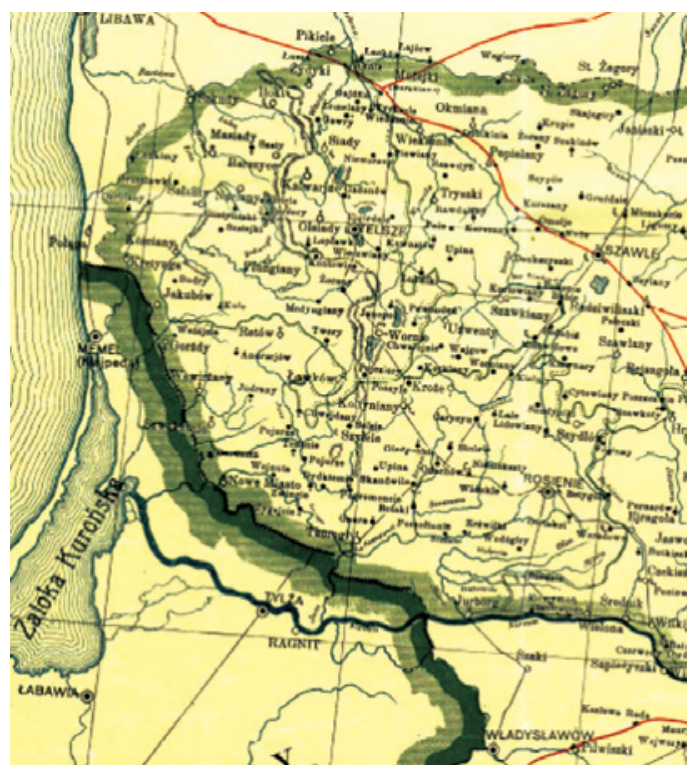

Fig. 42. Samogitia on the map of Gubernias of Lithuania and Belorus by Benedykt Hertz, 1905

Source: http://staremapy.org/pdfmap/Litwa_i_Bialorus_1905.pdf

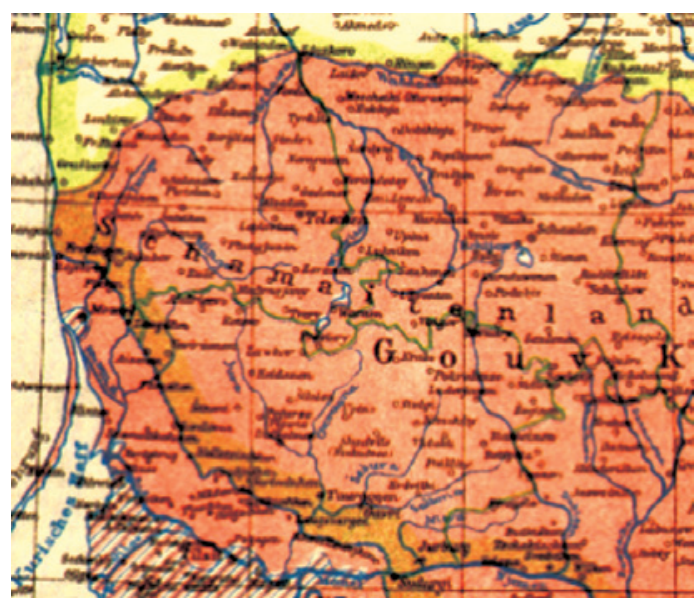

Fig. 43. Samogitia (Schamaiten land) on the Etnographic map Lithuania by V. Gaigalaitis, 1917

Source: (Gaigalaitis 1917)
Uber Das Weltgebaude. Herausgegeben Von Adolf Stieler. Gotha Justus Perthes, 1873. Full title: Ost-Europa, No. 3: Sud-Schweden, die Russischen OstseeProvinzen, Polen \& West-Russland. Scale 1:3 700000.

Stieler's Hand Atlas Uber Alle Theile Der Erde Und Uber Das Weltgebaude is extraordinarily detailed. Close examination of the maps shows many features that one would expect to find only on much larger maps. This atlas was first published in 1817, with editions continuing well into the 20th century. It was one of the most comprehensive and best executed 19th century German atlases. In this edition, the maps are dated 1871-1875.

By the end of the $19^{\text {th }} \mathrm{c}$. the Czarist Russia possessed stocks of different maps which had both Lithuania and Samogitia. They also had dense hydrographic nets, a number of settlements, as well as designed boundaries of provinces and counties (Fig. 41). In the nicks one may find the plans of the most significant administrative centers (Kaunas, Vilnius, Šiauliai, Telšiai).

In Fig. 42 Samogitia on the map of Gubernias of Lithuania and Belorus by Benedykt Hertz published by Edmund Nowickij in Kuryer Litewski (The Lithuanian Courier, Lithuanian newspaper).

In Fig. 43 Samogitia in the map with the title "Etnographische karte von Litauen" [Etnographic map of Lithuania] from book by V. Gaigalaitis (1917). In the map is marked the Lithuanian language areas and linguistically mixed areas. Samogitia is attributed to the Lithuanian language area.

Vilius Gaigalaitis (Wilhelm Gaigalat) (18701945) was political, public and cultural figure in Lithuania Minor, doctor of Theology, professor. In the Lithuanian and German press published articles on church and public issues. He wrote 25 books and booklets.

\section{Reflection Cristianity of Samogitia on the maps}

In the 15th century, Samogitia was the last region in Europe to be converted to Christianity. In 1413 Vytautas and Jogaila accompanied by several priests began baptizing the population. In 1415 a delegation of sixty Samogitian nobles visited the Council of Constance to announce the territory's conversion. The diocese of Samogitia or Medininkai was established in 1417, with its center at Varniai. Vytautas endowed the diocese with land and provided funds for the construction of the cathedral and parish churches (in Ariogala, Kaltinènai, Kelmè, Kražiai, Luokè, Raseiniai, Veliuona, 
Viduklè). The first bishop was Canon Matthew of Vilnius, who administered the diocese from 1417-1422. But the conversion of the Samogitian population proceeded very slowly, especially in the more remote areas; as late as the 16th century, there were only 38 churches and the people still practiced their pagan religion. Consequently the Calvinist Reformation movement had a great success in Samogitia, particularly among the nobility. Protestantism, however, was not able to survive the Catholic Counter Reformation, which was led by the Samogitian Bishop Merkelis Giedraitis (dead 1609). Of considerable significance to the religious and cultural life of Samogitia was the Jesuit college at Kraziai (1616-1773). The $17^{\text {th }}$ century the Marian Shrine at Siluva gained wide recognition throughout the country. The Samogitian countryside became and miniature chapels erected along the roadways, in farmsteads, and cemeteries. The Jesuits had been invited by Bishop Giedraitis in 1608; a few years earlier the Franciscans had settled in Kretinga (1602).

The fragment of the map of Poland of 1526 created by Bernard Wapowski, covering almost the entire area of historical Samogitia, can be viewed as a source for studies of the network of Catholic churches and parishes of Samogitia of the beginning of the 16th century (Bucevičiūtè 2007).

Only about 1760 in Nesvyžius was created Bernardine monasteries distribution in the Grand Duchy of Lithuania map scale 1:1 700000 engraved by Herszek Leybowicz which marked 28 monasteries (Fig. 44). The map is stored in the Library of the Lithuanian Academy Sciences.

Herszek Leybowicz (1700-1770) was a self-educated artist, and not all of his carvings were a success. Most of the portrayed seem very alike, their individual traits are distinct only in some of the works. H. Leybowic carved on copper tablets. This technique was widely applied in reproduction of paintings.

The researhers of the old Lithuania culture are well-acquainted with the personality of Stanislovas Čerskis (Stanislaw Czerski) (1777-1831), a canon of Samogitia, the author of the booklet "Opis Žmudzkiey dyecezyi" published in Vilnius in 1830 (Description of the Diocese of Samogitia). This simple and laconic book gives plenty of statistical information but fewer personal notices and insights as well as historical excursus. It is also the first attempt to overview Samogitia Dioceze and present it to the public and also the first try of both visually and cartographically illustrated description of Samogitia Dioceze (Fig. 45), Skuodas Deanery and Salantai Parish. It could be treated as one of the first works of primary regional studies in Lithuania (Czerski 1830).

The diozese of Samogitia covered a major part of Lithuania and was highly important in its history. Requested by the Bishop M. Valančius an outstanding person of Samogitia Juozapas Juzumas having analysed Kaunas Gubernija map, designed by Russian military topographers and having selected geographical objects, suitable for cartography as well as other special elements together with his brother Vincentas

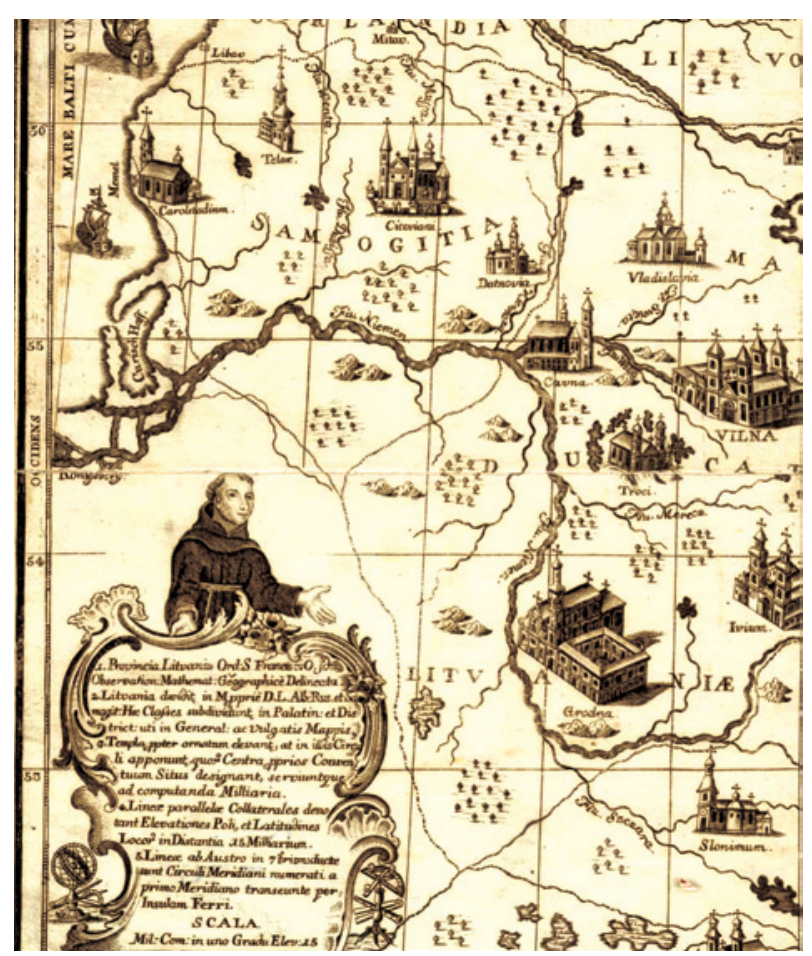

Fig. 44. Samogitia on the map of Bernardine monasteries in the Grand Duchy of Lithuania by Herszek Leybowicz Provincia Litvana, 1760

Source: http://viduramziu.istorija.net/etno/leybowicz-en.htm

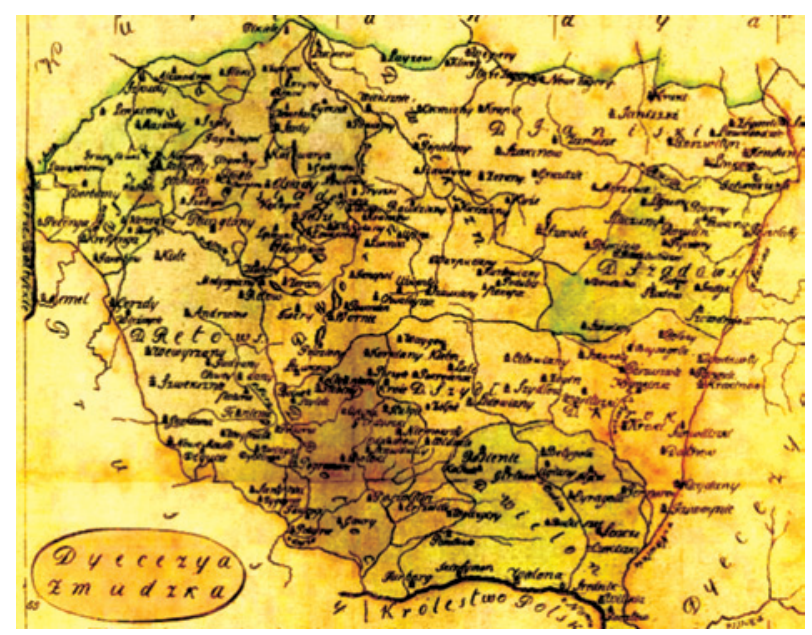

Fig. 45. Map of the Diocese of Samogitia, Vilnius, 1830 Source: (Czerski 1830) 
designed the map of the Samogitia Diozese (Fig. 46). That is a valuable $19^{\text {th }}$ century rarity and is counted to be both cultural and cartographical value from that period.
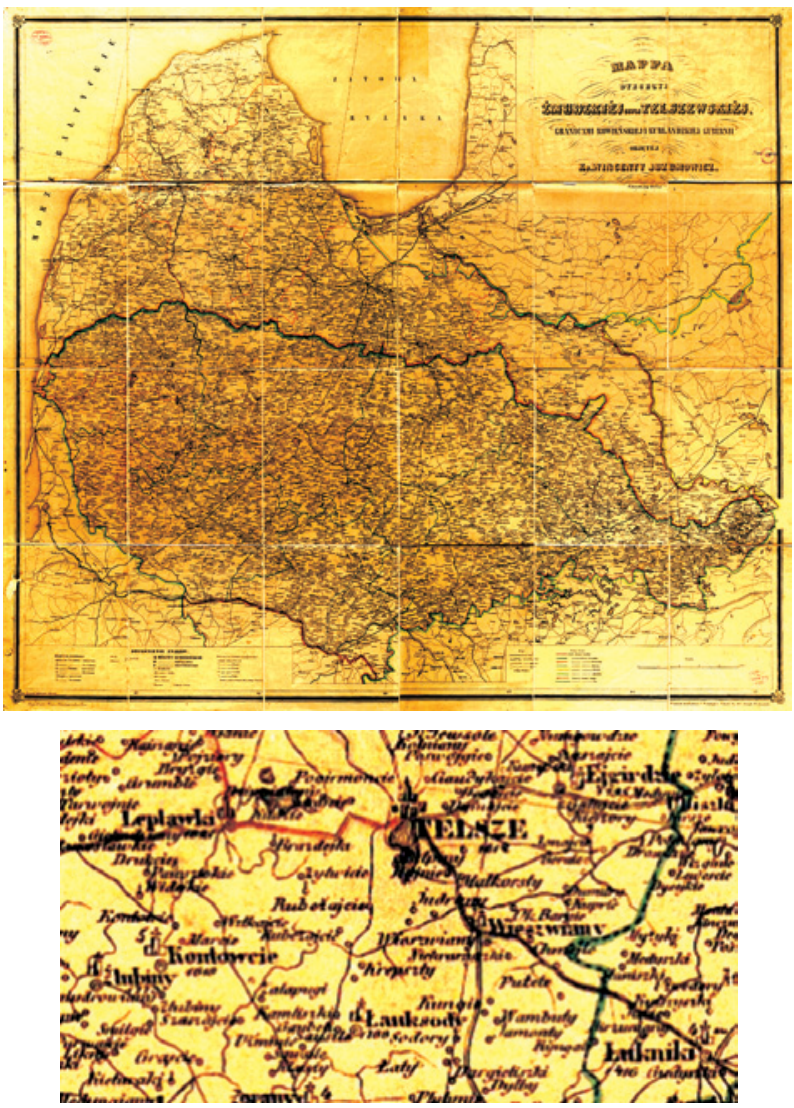

Fig. 46. Telšiai Diocesan map in Samogitia and its fragment. J. Juzumas, 1855

Source: http://ausis.gf.vu.lt/mg/nr/2001/02/2zv.html

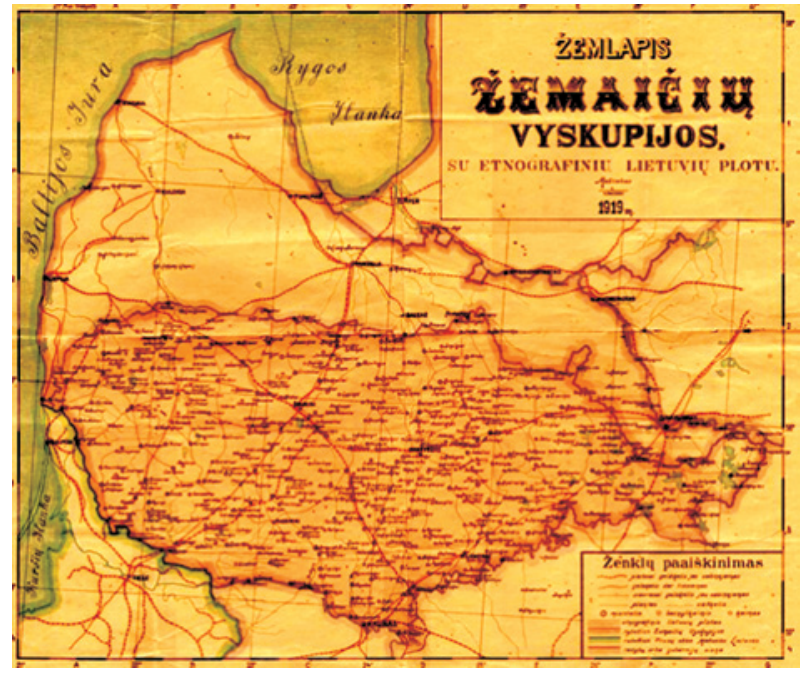

Fig. 47. Diocesan map of Samogitia with ethnographic area by J. Franckevičius, $1919 \mathrm{~m}$.

Source: http://www.maps4u.lt/lt/includes/siuntiniai/Z/J.Franckevicius_Zemaiciu_vyskupija_1919_.jpg
Fig. 46 shows the Samogitia Dioceze map, as designed by Juozapas Juzumas. It is a rare Central Lithuanian cultural and cartographical value of the $19^{\text {th }}$ century. The map gives a detailed cartographical view (rivers, lakes, roads, settlements, etc.) from Latvia to the Nemunas, from the Baltic Sea to Breslauja. As its geographical basis J. Juzumas used the map of the general staff of Czarist Russia. Evidently the author remade it and translated Russian names of geographical objects into a fashionable language of that time - Polish.

The map is really professionally designed despite the fact that its author was not a cartographer. It includes all the elements of a true map: mathematical framing, geographical grid, scale and arbitrary signs. The map scale is 1:480 000. A. Samas gave a much broader description of the map ending it with the following sentence: "We can be proud of having a rich map of Samogitia Dioceze and we can value it as a precious heritage of enlightened people for the researchers of Lithuanian cartography" (Samas 2006).

Fig. 47 Diocezen map of Samogitia with ethnographic area of Lithuania by J. Franckevičius.In this map the different symbols is used to note cities, towns, villages with churches and without its. Also is shown Lithuanian ethnographic area and borders of Samogitia Dioceze. This map is exceptionally valuable for its detailed borders of Samogitia as well its settlements.

\section{Samogitia on the maps between two World wars (1920-1939)}

Russia annexed Lithuania at the end of the $18^{\text {th }}$ century and in 1918 the state regained its independence. In 1920 Constitutive Seimas outlined the State's, defended in battles, political system with regard to its national background. The Seimas declared Lithuania as a democratic Republic. The newly established state badly needed international support but the major states supported Poland and avoided to recognize Lithuania as a separate and independent state.

On the 23rd of March, 1918, the German Kaiser announced his recognition of the independence of Lithuania. However, until Germany capitulated in November that same year, Lithuania's international status remained undefined. On the 12th of December, 1918, Sweden was the first state to accord Lithuania de facto recognition. Russia and the major countries of the world recognised Lithuania's independence during 1920-1922. Lithuania was admitted to the League of Nations in 1921. 
Lithuanian cartography greatly improved after 1918, after reestablishing its statehood The State of Lithuania was returned to world maps again (Fig. 48). A considerable number of maps was designed by Lithuanian professionals and published. Lithuanian topographical maps were started to be designed in 1922 . However, the implementation of these and similar intentions stopped in 1940, when the State was illegally occupied by the Soviet Union.

In Fig. 49 Samogitia in the map of Lithuanian Republic (in English). Scale 1:2400000, Creator Jonas Žilius, published in book "Lietuvos rubežiai. Istoriškai etnografiška studija”. New York (C. S. Hammond and Co.), 1920.

Jonas Žilius (1870-1932) being a priest, public-spirited, publicist and poet, translator, researcher, banker and diplomat has so far been a poorly acknowledged participant in the history of Lithuanian culture. He managed to accomplish a lot in the public life of Lithuanians in the USA and also contributed in attaching the land of Klaipeda to Lithuania.

In 1893 he graduated from Overbrook (USA) divinity seminary. During 1893-1908 and 1916-1921 he lived in the USA. In 1910 - 1914 he studied in Zurich and Berlin Universities. In 1917-1919 he was a member of Lithuanian Nation Board in the USA and represented its Lithuanians in Paris Peace Conference which tried to define Europe after the end of the World War 1. The conference signed the Versailles treaty.

At that time namely, a term the land of Klaipeda appeared. During 1925-1926 Jonas Žilius was the governor of the land.

Fig. 50 Samogitia 1:1 050000 scale in the map of Lithuania. The map is an appendage of the publication "The Peace Treaty of Lithuania and Russia". The Treaty was signed in 1920, July 12 . According to the Treaty, Russia acknowledged the declared state's independence in the act of February 16, 1918, so its eastern border was marked.

In Fig. 51 Samogitia in the map of Lithuania published by press Keleivis, Boston, USA, 1921. Boundaries of Lithuania shown as comfirmed acc agreements or as government considers. Area of Samogitia on this map is not differentiated from Lithuania.

E. Debë's "The small school map" atlas consists of 20 pages and is meant for the elementary schools. A. Vireliūnas prepared it for Lithuanian schools. Švyturys Publishing House printed it. Kaunas - Vilnius 1923. The page No. 4 is dedicated to Lithuania. The scale is 1:2000000 (Fig. 52).

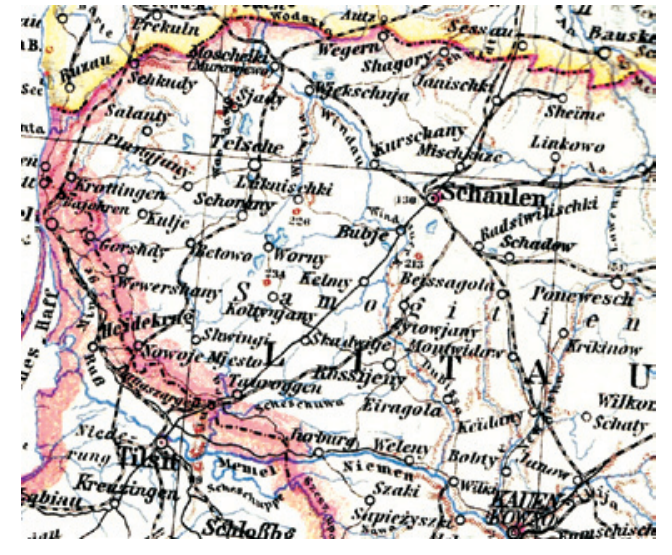

Fig. 48. Samogitia (Samogitien) on the German map of Lithuania, 1919

Source: http://lithuanianmaps.com/images/1919_Steilers_Westrussland_ak_DETAIL.jpg

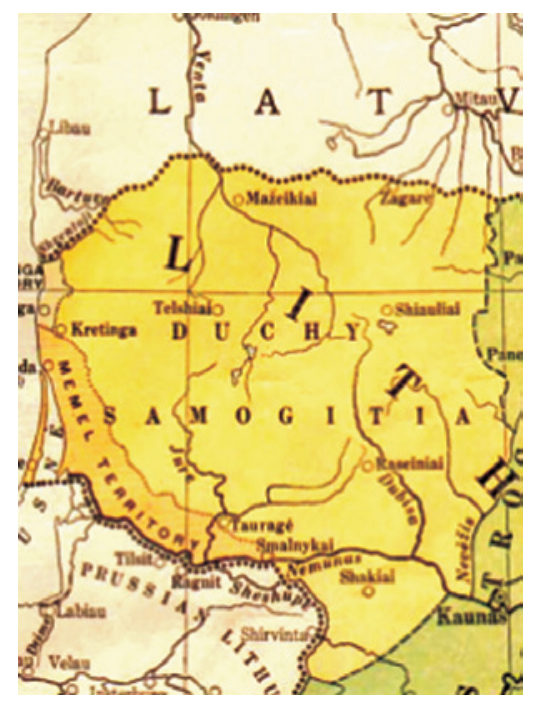

Fig. 49. Samogitia on the map of Lithuania by Jonas Žilius, New York, 1920

Source: http://maps4u.lt/en/maps.php?cat=66

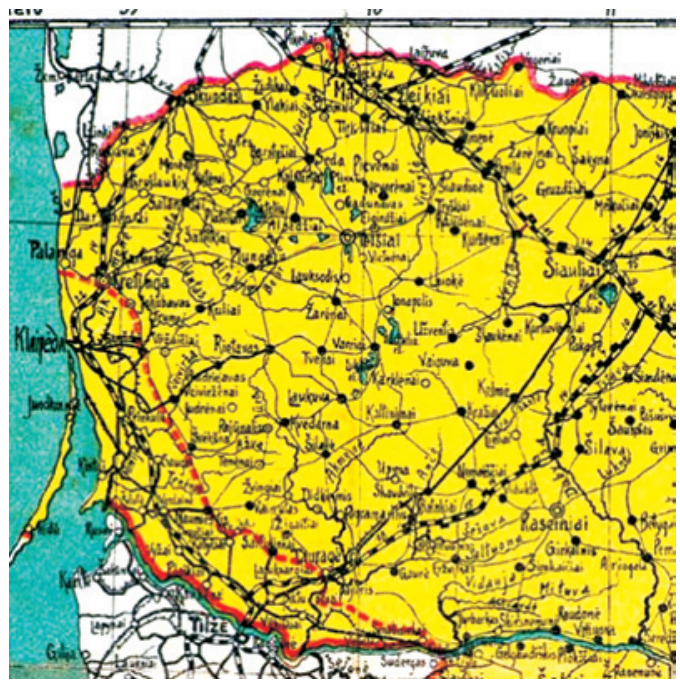

Fig. 50. Samogitia on the map of Lithuania, 1920 : http://www.lnm.lt/fotos/virtualios_parodos/zemelapiai/24.jpg 


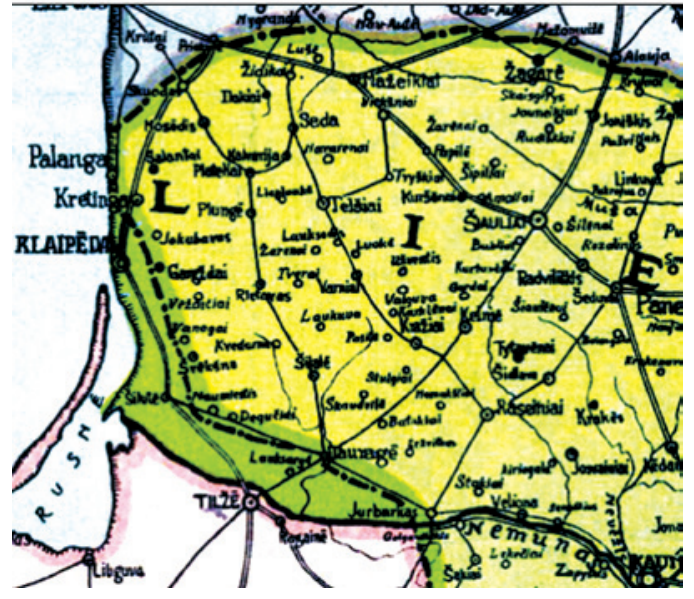

Fig. 51. Samogitia on the map of Lithuania, 1921

Source: http://www.maps4u.lt/lt/includes/siuntiniai/Z/Lietuvos_Respublikos_zemelapis_Keleivis.htm

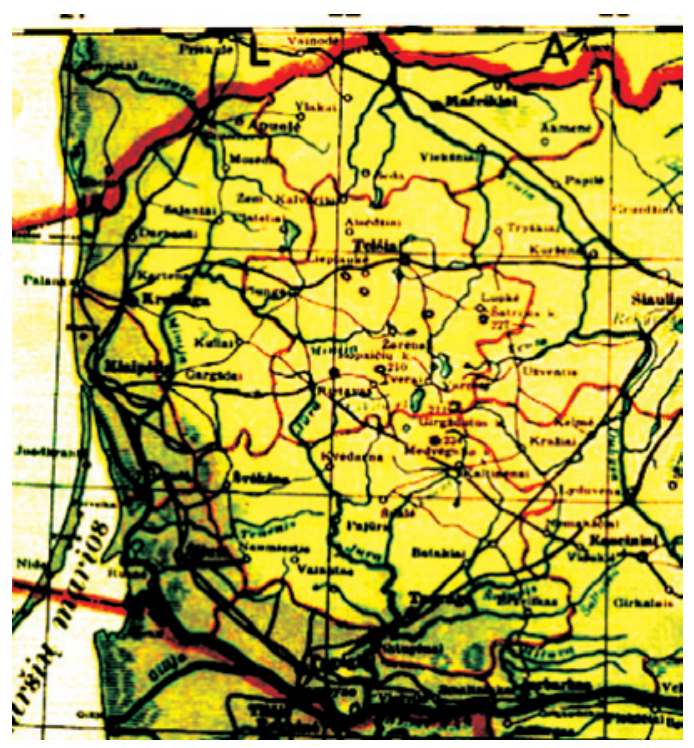

Fig. 52. Samogitia on the map of Lithuania by A. Vireliūnas, 1923

Source: http://www.maps4u.lt/lt/includes/siuntiniai/Z/Lietuvos_zemelapis_1938_vireliunas.htm

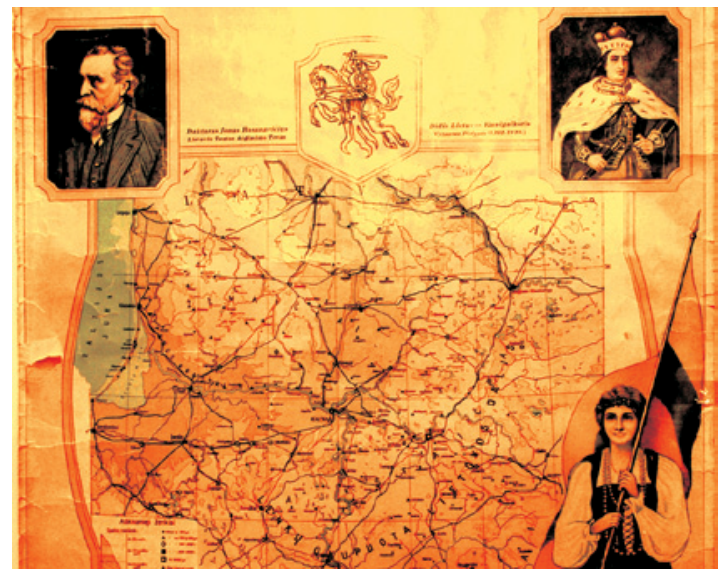

Fig. 53. Samogitia on the map of Lithuania by Lithuanian "Lithuanian Vienybè publishing Co.", A. Hoen \& Co, Baltimor, USA, 1929

Source: http://www.menorinka.lt/pdf/katalogas8.pdf
During the interwar Antanas Vireliūnas (18871950) was treated to be the initiator of scientific geography in Lithuania. In 1922 he designed a world globe in Lithuanian. Most likely that the globe designed by A. Vireliūnas and printed in „Švyturys“ company is the first Lithuanian globe.

In Fig. 53 Samogitia in the map of Lithuania (with Jonas Basanavičius and Vytautas Magnus portraits). Author is undefined. Map was printed in " $\mathrm{Li}$ thuanian Vienybė publishing Co.", A. Hoen \& Co, Baltimor, USA, 1929.

This map was distributed in different communities in the USA and the received revenue was donated for Lithuania which at that time was suffering from the world economic crisis.

In Fig. 54 the Smogitia is shown in the map of Grand Duchy of Lithuania (Wielkie Księstwo Litewskie $\mathrm{w}$ drugiej połowie XVI wieku) in the middle of XVIc. Map is created by Jan Jakubowski. Map is characterized by the fact that it is very clearly marked boundaries and location. On the map, as an administrative unit is noted Samogitia. In the area of Samogitia is a record "ZEMIA ZMUDZKA". Author Jan Jakubowski itself provides a fairly detailed description of the map and based the administrative division of the Grand Duchy of Lithuania (Jakubowsi 1928).

In Fig. 55 Samogitia in 1398-1409 on the historical map of Lithuania by O.Girčytè-Maksimavičienè.

Ona Girčytė- Maksimavičienė (1902-1999) historian, educator, one of the first historical cartography experts drawn maps of textbooks, atlases.

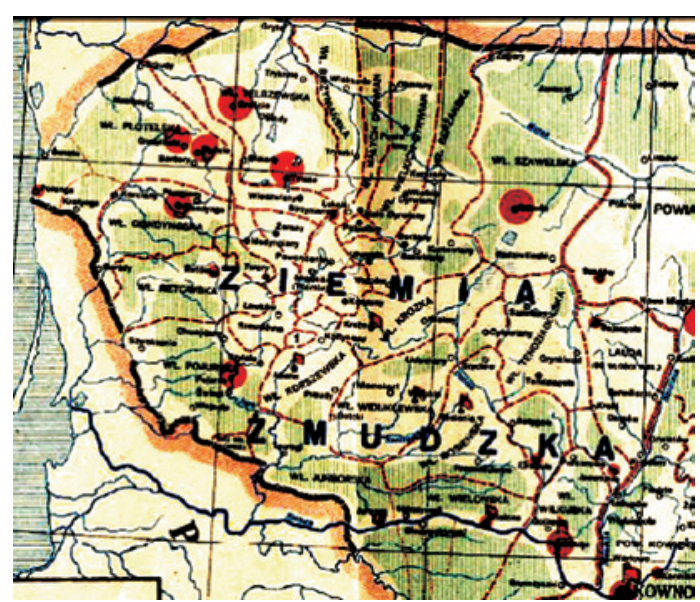

Fig. 54. Samogitia on the map of Grand Duchy of Lithuania in 16th c. by Jan Jakubowski, Lvov 1927

Source: http//pbc.biaman.pl/dlibra/doccontent?id=12205\& dirids $=1$ 


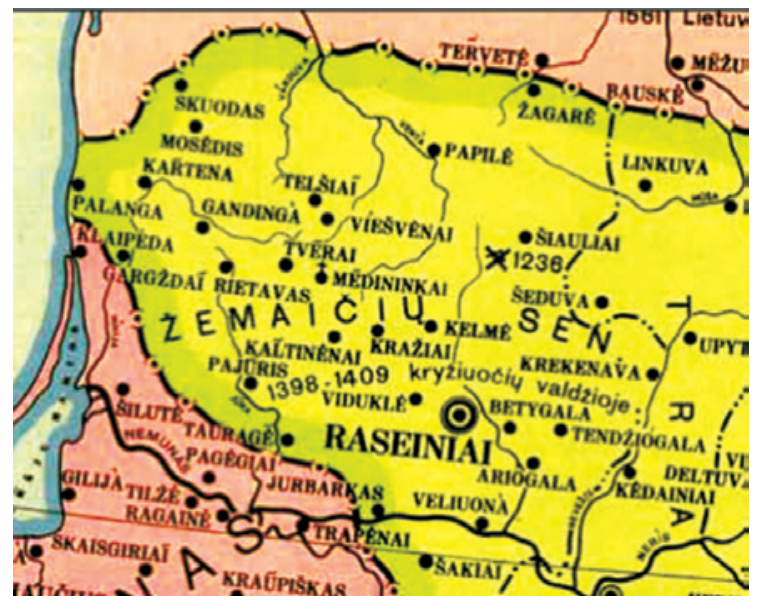

Fig. 55. Samogitia in 1398-1409 on the historical map of Lithuania by O.Girčytè-Maksimavičienè, Kaunas, 1937

Source: http://www.maps4u.lt/lt/includes/siuntiniai/Z/Istorinis_ Lietuvos_zemelapis_iki_XVIa.vidurio_1937.htm

\section{Reflection of historical Samogitia on the maps of nowdays creators}

Inexhaustible treasures belong to Samogitia's natural surroundings, history, people and culture. Perhaps the pretty stubborn character of local people created such an amazing spirit of Samogitia we see nowadays.

At present Samogitia is one of the four regions of Lithuania. The area of Samogitia is about $21,000 \mathrm{~km}^{2}$, encompassing Klaipeda, Telšiai, Mažeikiai, part of the Šiauliai, Taurage and Kaunas districts. The borders of the Samogitian region coincide only approximately with the borders of the Samogitian dialect.

Within the greater part of this territory the inhabitants speak the Samogitian language (dialect). They have preserved their traditional way of life and customs.

Samogitia population is about 500000 inhabitants. The inhabitants of the region still adhere to their traditional lifestyles. They are one of the several ethnic groups in Lithuania and they strive to retain their indigenous language and culture. The region uses three variations of local dialect. On the basis of these variations, the region can be demarcated into three main divisions. The people of Samogitia who inhabit the districts like Akmené, Kretinga, Skuodas, Palanga, Mažeikiai, Telšiai and Plunge are known as northern Samogitians. The southern Samogitians comprise of the inhabitants of Šilalè, Kuršenai, Taurage, Raseiniai, Varniai and Kelmè. The people of the districts of Priekulè, Šilutè, Klaipeda are known as the western Samogitians (Regions... 2014).

In Fig. 56 Samogitia in the map of Poland and Lithuania after Lublin Union by Vanda Daugirdai-
tè-Sruogienè from her book History of Lithuania (Daugirdaite 1990).

Vanda Daugirdaitė-Sruogienė (1899-1997) historian. She collaborated in various periodicals publications in Lithuania and abroad. She is author of Lithuanian history and several other books and editor of the history department of Lithuanian encyclopedia published in Boston.

Fig. 57 the map gives an artistic picture of Samogitia Duchy in the $18^{\text {th }}$ century. It was published by Samogitian Cultural Association in 1999. The map was designed under the coordination with historian Elmantas Meilus, Lithuanian Institute of History, its artist Arvydas Každailis. In it Samogitia lacks the south-eastern part. The eastern borders of Samogitia

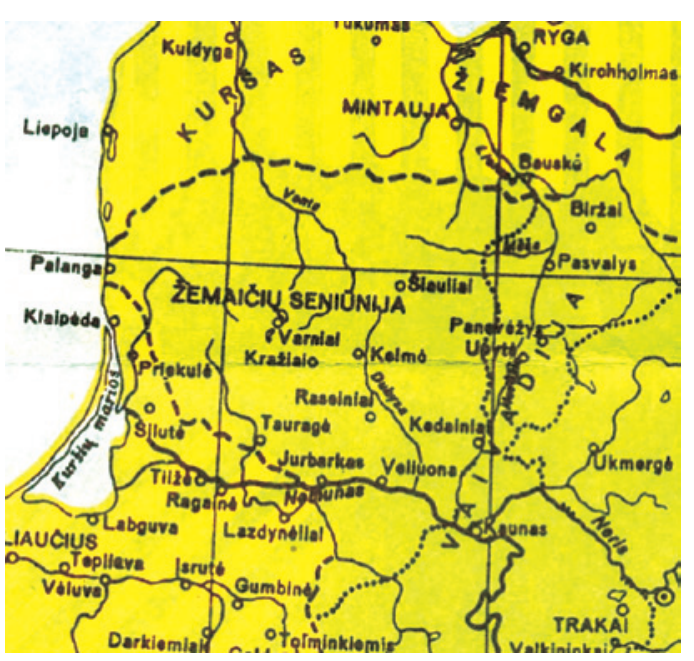

Fig. 56. Samogitia on the historical map of Poland and Lithuania after the Union of Lublin (1569) by DaugirdaitèSruogienè, Vilnius, 1990

Source: http://foto.terpe.lt/inkelti/20110224/i81_DG-lt-lubl.jpg

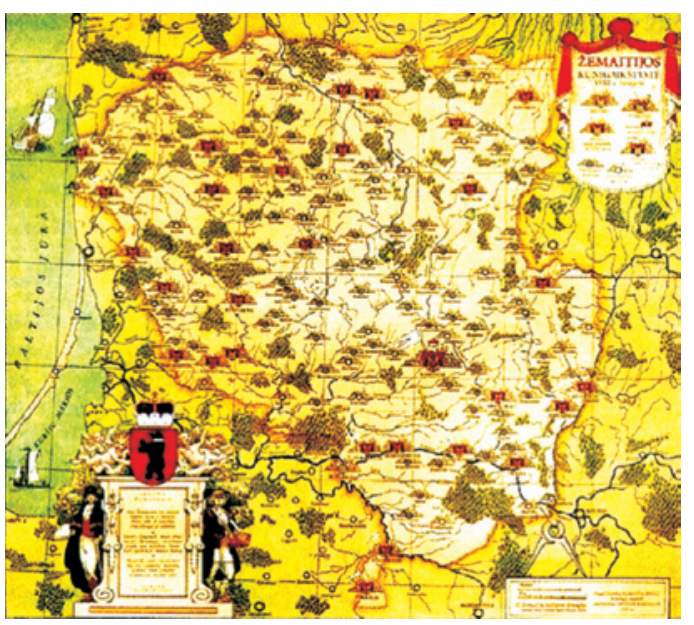

Fig. 57. Samogitia Duchy at the end of $18^{\text {th }} \mathrm{c}$. Published in 1999 by initiative of the Cultural Society of Žemaitija

(Samogitia). Map drawn according to historian Elmantas Meilus. Artist Arvydas Každailis

Source: http://samogitia.mch.mii.lt/ISTORIJA/is_istorijos.htm 
most probably coincide with those, dated 1398, October $12^{\text {th }}$ when Vytautas Magnus signed the contract with Teutonic Order; according to the contract the Grand Duchy gave the Order Samogitia land up to the Nevezžis River. So, Vytautas gave the Order not the whole Samogitia, but its major part -up to the Nevezžis. Fig. 57 shows the incomplete map of the Duchy of Samogitia, but only the part, given to the Order. However, the situation of the $18^{\text {th }}$ century as depicted in the map does not match the real situation of that time (Jankauskas 2013).

In Fig. 58 map territory of Samogitia more or less matches the future land of Samogitia Neighbourhood (historical part of Samogitia West from the Nevėžis,

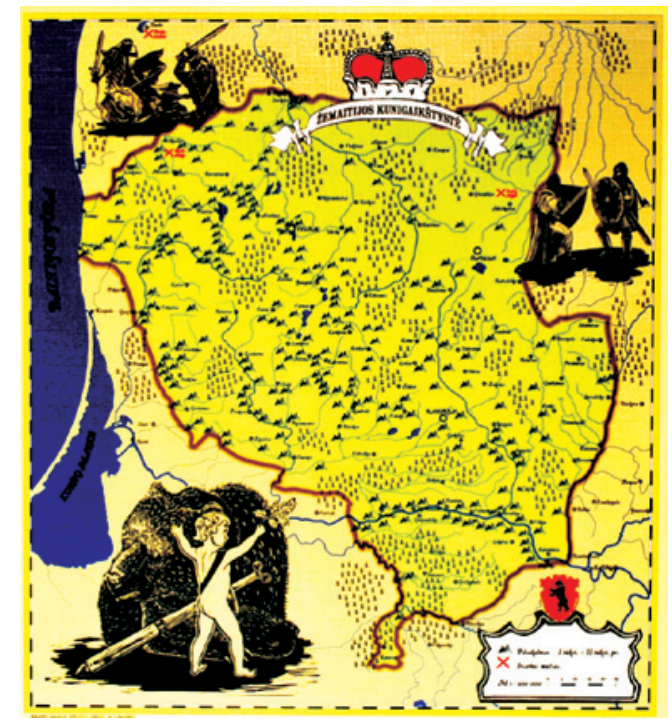

Fig. 58. Samogitia Duchy at the $14^{\text {th }}$ c. Created in 2012 by initiative of Taigra

Source: http://www.taigra.lt/zemaitijos-kunigaikstyste/

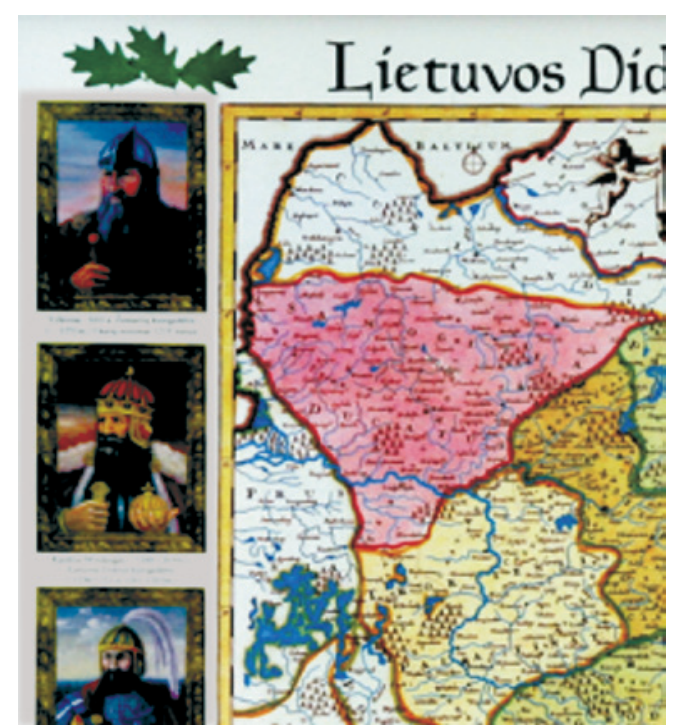

Fig. 59. Samogitia on the map of the Grand Duchy of Lithuania in $18^{\text {th }} \mathrm{c}$. Author archives: Taigra, 2012

Source: http://www.taigra.lt/lietuvos-didzioji-kunigaikstyste-2/ including present north-west corner of Užnemunè). Its artist is Karolis Dedūra (Taigra 2012).

In Fig. 59 Samogitia on the map of the Grand Duchy of Lithuania in $18^{\text {th }}$ c., from Author archives: Taigra.

In Fig. 60 the sculpture "The Globe of Samogitia" in Telšiai, Lithuania. Author Artūras Valiūnas. Architect Algirdas Žebrauskas. Built in 2008. The author's idea of a cultural object is a smart answer to those who think that there are no Samogitians. The areas of Samogitia depicted on The Globe of Samogitia correspond to the actual map, and Telšiai, like Rome, stands on seven hills.

Where is Samogitia nowadays? Fig. 61 shows a segment of a map of Lithuanian ethnographical

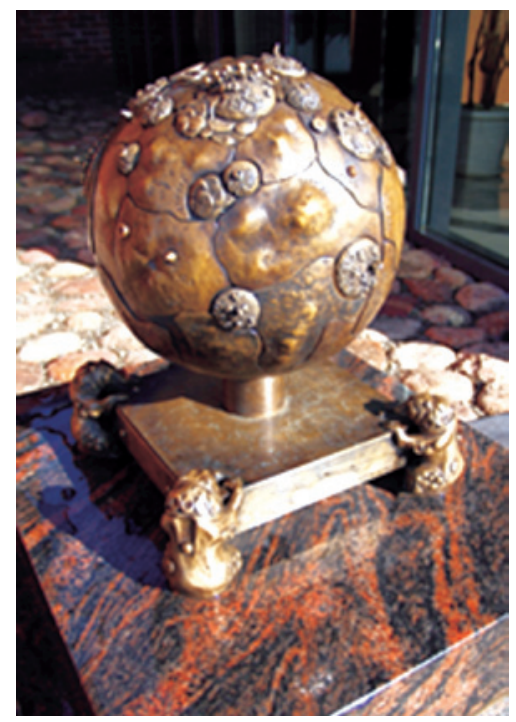

Fig. 60. The Sculpture "The Globe of Samogitia”. Author Artūras Valiūnas, architect Algirdas Žebrauskas, Lithuania Source: http://www.telsiaitic.lt/16822/famous-places/smallsculptures.html

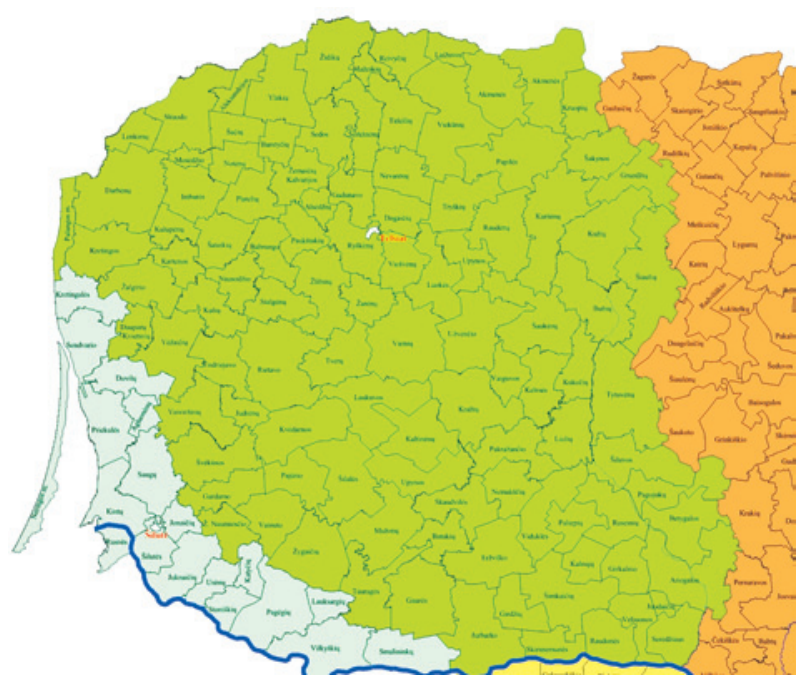

Fig. 61. Samogitia on the map of Lithuania ethnic regions by D. Pivoriūnas and Ž. Šaknys

Source: http://www3.lrs.lt/owa-bin/owarepl/inter/owa/ U0123191.jpg 
regions. The map was designed on the basis of different scientific research and conclusions by experts in ethnology, ethnomusicology, linguistics, history, etc. as well as their recommendations and after reviewing over 200 ethnographical maps. The basic criteria to set the borders of Lithuanian ethnographical borders were as follows: regional distinction in culture of material and spiritual appearances.

The authors are sure that the map of Lithuaniass ethnographic regions will help the people to better know the borders of cultural distinctions, what ethno cultural traditions should be cherished and which unique values should be preserved.

\section{Conclusions}

Cultural identity of Samogitians had a great impact on the development of the nation of Lithuania. An encouraging factor to prepare this publication was the respect towards the history of Samogitia and its cultural heritage, bearing a special historical value. This article is devoted to the significant event for the history of the whole Europe: a 600 year anniversary baptism Samogitia.

The maps thoroughly, vividly and informatively express the very essence of the fixed phenomenon or event which no other written document can do. One of the aims of the article is to encourage to more widely use maps as historical documents and to compare them with written information; which allows to assess an event or a historical period more clearly. The presented maps, in our opinion, fully reflect the peculiarities and variety of Samogitia.

We hope that the publication will encourage researchers to study the history of Samogitia using maps in more depth. This is what the authors of the publication as well as other mentioned authors have done. Our article provides helpful links for the readers interested in more detailed studies of specific maps.

Summarizing we can state that the above mentioned Samogitia and Lithuania maps by Lithuanian and foreign authors lack thorough historical analysis and attention to become scientific discussions, so the society of Lithuania is hardly aware of them. The historical problem of the Samogitia can be solved only by joined efforts of cartographers, linguists and historians. We hope that this work will become an additional step towards the problem solution.

\section{References}

Bucevičiūtè, L 2007. XVI a. pradžios Žemaitijos katalikų bažnyčios tinklo atspindys Bernardo Wapowskio 1526 metų žemelapyje [Reflections of the early sixteenth century network of Žemaitian Catholic Curhces in Bernard Wolpowski's 1526 map], Lietuvos metraštis, 2. Vilnius (in Lithuanian).

Chomskis, V. 1958. The cartographical expression of the territory of Lithuania (A historical review), Collectanea acta geographica Lithuania, 21-31 [online] [cited 2013]. Vilnius. Available from Internet: http://maps4u.lt/en/articles. php?cat_id=2.

Czerski, S. 1830. Opis Źmudzkiey dyecezyi [Description of the Diocese of Samogitia]. Vilnius (in Polish).

Daugirdaitė Sruogienė, V. 1990. Lietuvos istorija [History of Lithuania] Vilnius: Vyturys. ISBN 5-7900-0637-X.

Gaigalat, W. 1917. Litauen, das besetze Gebiet, sein Volk und dessen geistige Strömungen [Lithuania-occupied land, the people and its spiritual power]. Frankfrut: Frankfurter Vereinsdruckerei, Verlag, Frankfurt a/M, Hauprvertrieb für den Osten. 179 p.(in German).

Jakubowski, J. 1928. Mapa Wielkiego Księstwa Litewskiego w połowie XVI wieku, 1 [Map the Grand Duchy of Lithuania in the middle of $16^{\text {th }}$ c.]. Cracow. 22 p. (in Polish).

Jankauskas, B. 2013. Kokios yra istorinès Žemaitijos ribos? [What is the historical border of Žemaitija], Žemaičiu žeme 2: 4-7 (in Lithuanian).

Lietuvos Didžiosios Kunigaikštystès istorinès véliavos ir žemèlapiai. 2006. UNESCO Pasaulinio paveldo komiteto 30-osios sesijos tarptautinès parodos katalogas. TDM, Vilnius.

Lukoševičius, V. 2014. Cartographic image of Samogitia in the old maps of Lithuania, Poland and other neighboring countries (1231-1700), Geodesy and Cartography 40(1): 31-54. http://dx.doi.org/10.3846/20296991.2014.890317

Regions of Lithuania. 2014. [Online], [cited 2013]. Available from Internet: http://www.mapsofworld.com/lithuania/regions.html

Samas, A. 2002. Jono Nepreckio Lietuvos Didžiosios Kunigaikštystès žemèlapis [Map of the Grand Duchy of the Lithuania by Jonas Neprieckis], Mokslas ir gyvenimas 5: 26-28.

Samas, A. 2006. Žemaičiu vyskupijos žemélapis [Samogitian diocese map] [online], [cited 2013]. Available from Internet: http://samogitia.mch.mii.lt/VYSKUPIJA/vyskupzeme.htm (in Lithuanian).

Taigra: Paveikslai-plakatai. 2012. [Online], [cited 2013]. Available from Internet: http://www.taigra.lt/category/paveikslai/ paveikslai-plakatai/

Žilius, J. 1920. Lietuvos rubežiai. Istoriškai etnografiška studija [Boundaries of Lithuania.Historically ethnographic study]. New York: C. S. Hammond and Co. (in Lithuanian).

Viktoras LUKOŠEVIČIUS. Doctor, Prof. Department of Civil Engineering, Faculty of Technology, Šiauliai University Vilniaus g. 141, LT-76353 Šiauliai, Lithuania $(\mathrm{Ph}+37041595843$, fax +37041595832 ).

A graduate of Kaunas Polytechnic Institute (now Kaunas University of Technology), geodetic engineer, 1962. Doctor's degree at Institute of Surveying, Aerial Photography and Cartography, Moscow, 1966. Publications: 2 books, over 70 research articles; participant of conferences in USA, Brasil, Sweden, Norway, Russia. Fellowship Winner, NATO and Italy National Science Competition, 1996. Member of Association for the Advancement of Baltic Studies.

Research interests: history geodesy and cartography. 